\title{
Lending Standards, Productivity and Credit Crunches
}

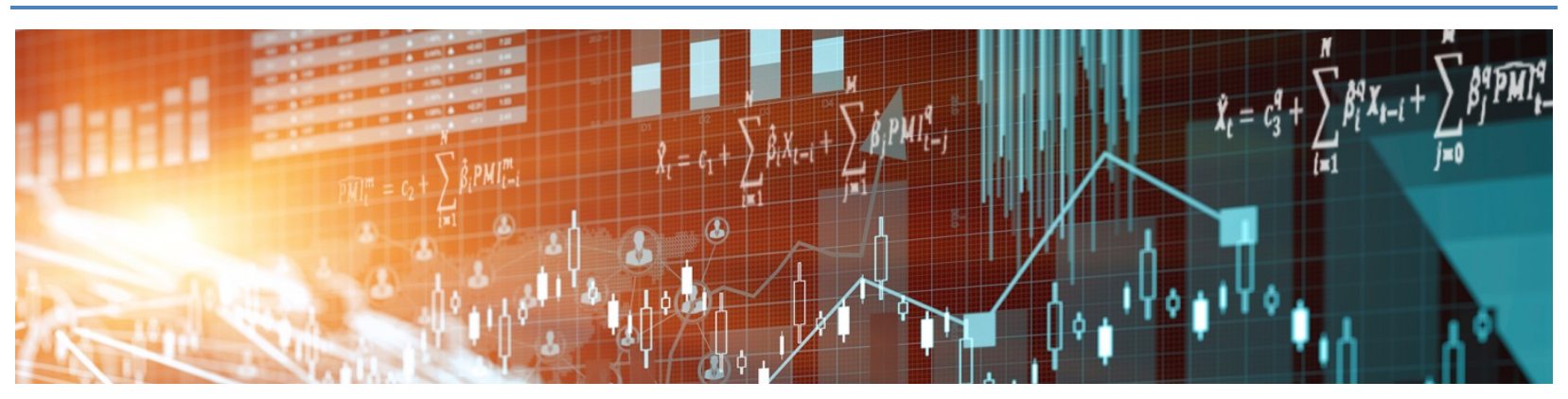

by Jonathan Swarbrick 
Bank of Canada Staff Working Paper 2019-25

July 2019

\title{
Lending Standards, Productivity and Credit Crunches
}

\author{
by \\ Jonathan Swarbrick \\ Canadian Economic Analysis Department \\ Bank of Canada \\ Ottawa, Ontario, Canada K1A 0G9 \\ jswarbrick@bankofcanada.ca
}




\section{Acknowledgements}

The paper was previously circulated with the title "Adverse Selection and Financial Crises." I am grateful to Tom Holden, Cristiano Cantore, Paul Levine, Vasco Gabriel, Antonio Mele, Martin Eichenbaum, Ben Moll, Charles Kahn and Stefano Gnocchi for helpful comments and suggestions. I am also grateful for comments from discussants and participants at several workshops and conferences. This paper was based on a doctoral theses chapter; the financial support of the Economic and Social Research Council [grant number ES/J500148/1] during this time is gratefully acknowledged. The views expressed

in this paper are those of the author. No responsibility for them should be attributed to the Bank of Canada. 


\begin{abstract}
We propose a macroeconomic model in which adverse selection in investment drives the amplification of macroeconomic fluctuations, in line with prominent roles played by the credit crunch and collapse of the asset-backed security market in the financial crisis. Endogenous lending standards emerge due to an informational asymmetry between borrowers and lenders about the riskiness of borrowers. By using loan approval probability as a screening device, banks ration credit following financial disturbances, generating large endogenous movements in total factor productivity, explaining why productivity often falls during crises. Furthermore, the mechanism implies that financial instability is heightened when interest rates are low.
\end{abstract}

Bank topics: Credit and credit aggregates; Business fluctuations and cycles; Interest rates; Financial stability; Financial markets; Productivity

JEL codes: E22, E32, E44, G01

\title{
Résumé
}

Nous proposons un modèle macroéconomique dans lequel l'antisélection dans les investissements amplifie les fluctuations macroéconomiques, ce qui cadre avec le rôle prépondérant qu'ont joué l'étranglement du crédit et l'effondrement du marché des titres adossés à des actifs durant la crise financière. Des critères de prêt endogènes apparaissent en raison de l'asymétrie d'information entre prêteurs et emprunteurs quant au degré de risque que présentent ces derniers. À la suite de perturbations financières, les banques rationnent le crédit en recourant à la probabilité d'approbation des prêts dans la sélection des emprunteurs. Cette situation provoque de grands mouvements endogènes de la productivité totale des facteurs, ce qui explique pourquoi la productivité a tendance à chuter en période de crise. De plus, le mécanisme implique que l'instabilité financière est plus élevée lorsque les taux d'intérêt sont bas.

Sujets : Crédit et agrégats du crédit; Cycles et fluctuations économiques; Taux d'intérêt; Stabilité financière; Marchés financiers; Productivité

Codes JEL : E22, E32, E44, G01 


\section{Non-technical summary}

\section{Motivation and question}

Banks vary the availability of business loans in response to economic conditions both by adjusting interest rates and by varying credit standards. These non-price standards are a result of banks not having full information on firms when they apply for loans. The bank must therefore use other terms, such as credit scores, collateral requirements and credit limits to distinguish good from bad. These standards play a potentially important but underexamined role in generating business cycles in advanced economies. This paper studies the channels through which financial disturbances affect macroeconomic outcomes, investigating the role of information asymmetries and the use of lending standards in the banking sector.

\section{Contributions}

We develop a model that attributes occasional contractions in credit to an information problem in business lending: some businesses are more likely to default than others, but lenders (or banks) cannot tell which firms are safe and which are risky. This problem is referred to as "adverse selection" and, in the model, causes banks to vary non-price credit standards, which can lead to sharp falls in credit to firms. Additionally, unlike existing models in the literature, this can lead to falls in productivity. We study the theoretical properties of this mechanism and analyze the link between interest rates and the risk of financial crises.

\section{Findings}

If risky firms have a higher return than safe firms when their investment is successful, we find that banks can offer loan contracts with different terms set so that the risky and safe firms choose the contract designed for them. Risky firms will choose a loan with higher interest rates if it offers a higher loan approval rating than safe loans because they would be more likely to be declined credit if choosing a safe loan with a low interest rate and lower approval. Safe borrowers will choose the safe loan since this is the only type of loan that they can repay. We also find that when the risk of default increases enough, as it did during the recent crisis, banks don't lend all available funds and restrict credit to safe firms. This rationing of credit causes a fall in productivity because there is a drop in the available capital being utilized in production. We further show that the risk of such a credit crunch is heightened and economic fluctuations are amplified when real returns on capital are sufficiently low. The intuition is as follows. The lower the return on capital is, the higher the risky firms' incentive to choose safe loans. The banks respond to this higher incentive by reducing the loan approval of safe loans in order to make the risky firms choose the contract designed for them. It is this reduction in safe loans that drives credit crunches in the model. 


\section{Introduction}

During downturns in economic activity, banks cut back lending both by increasing interest rates and by tightening other non-price terms such as credit scores, collateral requirements or borrowing limits (see figure 1). The use of these non-price lending standards to vary the availability of business loans is a natural result of information asymmetries; were there no asymmetries, banks could price the risk and vary lending rates accordingly, as in any frictionless market (see Lown and Morgan, 2006). In this paper, we present a macroeconomic model with endogenous lending standards that emerge due to an informational asymmetry between borrowers and lenders about the riskiness of borrowers. By using the loan approval probability as a screening device, banks ration credit in the face of heightened risk. We show that the credit friction maps to endogenous movements in both total factor productivity (TFP) and the marginal efficiency of investment. This is an appealing feature because economic downturns also typically coincide with falls in TFP; prominent recent examples are the large declines in TFP across many advanced economies following the 2007-08 financial crisis. $^{1}$ In the proposed model, adverse selection in investment drives occasional credit crunches that are observationally equivalent to TFP shocks through the lens of a standard dynamic stochastic general equilibrium (DSGE) model, shedding light on recent crisis episodes and giving insight into the factors that might contribute to future downturns.

It is typical in the macroeconomics literature on financial frictions to embed a simple contracting problem into an otherwise standard structural model: for example, costly monitoring in the case of Bernanke et al. (1999) and Christiano et al. (2010), and limited contract enforcement in the case of Gertler and Kiyotaki (2010). In light of the events of the financial crisis, with the credit crunch in mind in particular, the financial friction in the proposed model is caused by privately observed information about the risk of a borrowing firm's project leading to an adverse selection problem. Studying such a friction is a natural choice. In the consensus view of the financial crisis, there was a major role played by the collapse of the asset-backed securities market driven by adverse selection, ${ }^{2}$ and while the credit crunch that followed was partly because of banks cutting lending due to funding constraints (see, e.g., Shin, 2009), hidden information about borrower quality played a critical role in closing credit markets to small businesses. ${ }^{3}$ In our framework,

\footnotetext{
${ }^{1}$ As shown in figure 10 in the online appendix. One notable exception to this was rising productivity in the U.S. during the Great Recession. However, productivity fell during previous recessionary episodes in the U.S., for example in 1982 (Chari et al., 2007), and fell in most other advanced economies during the Great Recession.

${ }^{2}$ See, e.g., Beltran and Thomas (2010), Morris and Shin (2012), Bertsch (2013) and Camargo and Lester (2014).

${ }^{3}$ For instance, former Bank of England governor Mervyn King attributed the collapse of small business and mortgage lending to adverse selection in his Mansion House speech, June 2012 (http://www.telegraph.co.uk/ finance/economics/9332296/Sir-Mervyn-Kings-Mansion-House-speech-in-full.html). Although fairly uncontroversial, the empirical literature assessing the importance of adverse selection in credit markets is relatively limited
} 


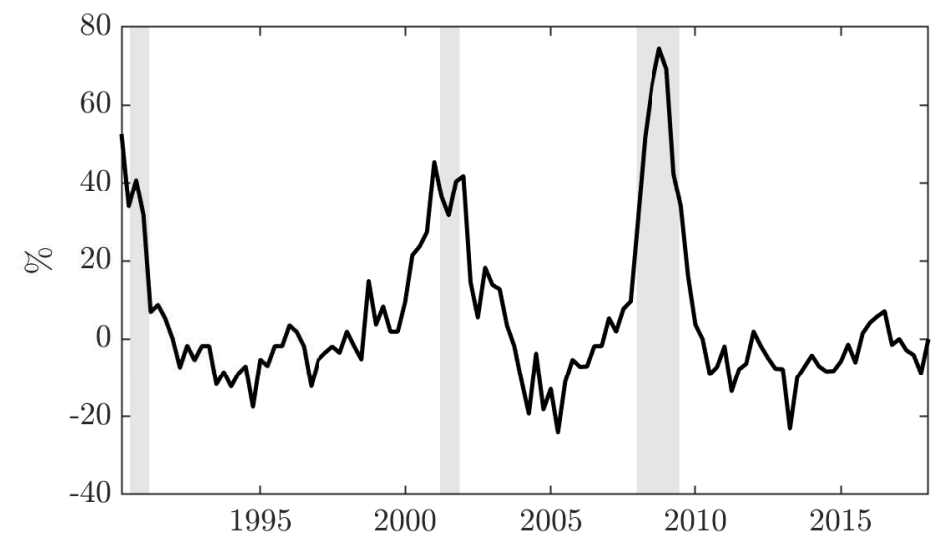

Figure 1: Net percentage of domestic banks tightening non-rate standards for commercial and industrial loans to small firms. Source: Board of Governors of the Federal Reserve System (BGFRS), Senior Loan Officer Opinion Survey on Bank Lending Practices.

some firms have no hidden information and therefore face no financing frictions. These can be considered equivalent to larger businesses in the data, which make up approximately $50 \%$ of employment in the U.S. ${ }^{4}$ The remaining firms, considered equivalent to small/medium-sized businesses (SMBs) can either be highly productive and risky or less productive and safe, but their type is private information. Whereas a decentralized market functions well for the firms without hidden information, intermediaries can perform better by screening between these firms. We characterize the firms as small in part by assuming their projects are indivisible; while large firms might choose investment across a range of projects, a small business may seek credit to open a single store or build a new factory. Defining projects as indivisible blocks is a caricature but captures salient features of smaller businesses, in particular, being unable to diversify risk. The assumption also implies limitations on the type of screening available to intermediaries. Although banks tighten lending standards using a variety of measures, recent survey evidence indicates that borrowers are more often unsuccessful in loan applications due to a lack of credit history and perceived tighter restrictions than due to the amount of credit requested or having insufficient collateral. ${ }^{5}$ In this paper, intermediaries can separate borrowers by offering a lottery

and inconclusive. Crawford et al. (2018) and Albertazzi et al. (2017) separately find evidence for adverse selection in Italian lending markets. Cressy and Toivanen (2001) find no evidence for adverse selection in 1987-1990 U.K. bank lending data, whereas Tang (2009) provides evidence of asymmetric information in U.S. credit markets using a Moody's credit rating refinement in 1982, and finds that it has significant impact on economic outcomes.

${ }^{4}$ Between 1988 and 2015. Source: The Statistics of U.S. Businesses (SUSB). See also footnote 22.

${ }^{5}$ See, for example, (Robb and Farhat, 2013, table 2, p. 5) and (Battisto et al., 2018, p. 8). The data on loan approval rates is limited at this point in time: the Federal Reserve Bank (FRB) of Kansas City has been collecting data from lenders since 2018 in the Small Business Lending Survey, and a joint project with several FRBs has been collecting national data from borrowers in the Small Business Credit Survey since 2015. Earlier public data 
for funding, charging risky borrowers higher interest rates by promising a higher chance of being approved for a loan. There is evidence for this relationship in the data because banks that are more likely to approve loan applications tend to charge higher interest rates. ${ }^{6}$

The adverse selection introduces two key effects: a counter-cyclical spread between the return to capital and the real interest rate due to counter-cyclical information rents and movements in TFP caused by the misallocation of capital. The underlying mechanisms behind these outcomes are understood by examining the screening process and resultant information rents. Safe and risky firms differ in the chance their projects will succeed and, when successful, risky firms enjoy a higher return than safe firms. For simplicity, we assume the ex ante value of safe and risky projects are equal under symmetric information, so heightened risk of failure is offset by higher returns when successful. It follows that a risky firm will be able to pay higher interest rates for finance than a safe firm but will have some probability of default. Therein lies the problem of the lender. Banks are only able to offer safe firms credit by either funding risky firms at the same rate, absorbing the default loss, or somehow reducing the value of a safe loan to risky borrowers so they opt for the loan designed for them. This is achieved through a probability of loan approval: supposing a safe loan is approved with an $80 \%$ probability, the surplus the risky borrower would earn by choosing the safe loan is cut by $20 \%$. The bank can then charge risky firms a higher interest rate than safe firms, providing enough surplus is left to the risky firms as incentive to reveal their type; i.e., they would earn weakly more than opting for a lower-interest safe-firm loan. This surplus is defined as the information rent. It follows that the amount the risky firms earn depends on the difference between the expected return on safe and risky projects which, in the model, is determined exogenously. It is these information rents that cause the spread between the real interest rate and the return to capital in the model. As we assume changes in the default risk of firms are off-set by changes in the returns of successful firms, there is no net effect on the ex ante value of a firm's project. In a first-best world, there is no impact of heightened risk because lenders can diversify. However, with asymmetric information, the risky firms will earn more information rents as the value of selecting the low-interest safe loan would be higher. This causes an increase in the spread and thus materializes as a fall in the marginal efficiency of investment, depressing economic activity.

The second key effect of the credit friction is to cause movements in TFP. Sharp downturns can occur when information rents rise to such an extent that lenders restrict funding to safer firms because doing so reduces the value of safe loans to risky firms, allowing lenders to raise risky lending rates. Key to this is a storage technology allowing banks to store a proportion of funds,

is inconsistent and sporadic, although approval rates have been shown to vary considerably.

${ }^{6}$ In 2015, 58\% of business loan applications to large banks were approved, whereas $76 \%$ of applications to small banks were; the average interest rate charged on business loans classed as moderate risk was $2.38 \%$ by large domestic banks, but $4.13 \%$ by small domestic banks. Source for approval rating from Barkley et al. (2016) and for interest rates from the FRB E.2. Survey of Terms of Business Lending. 


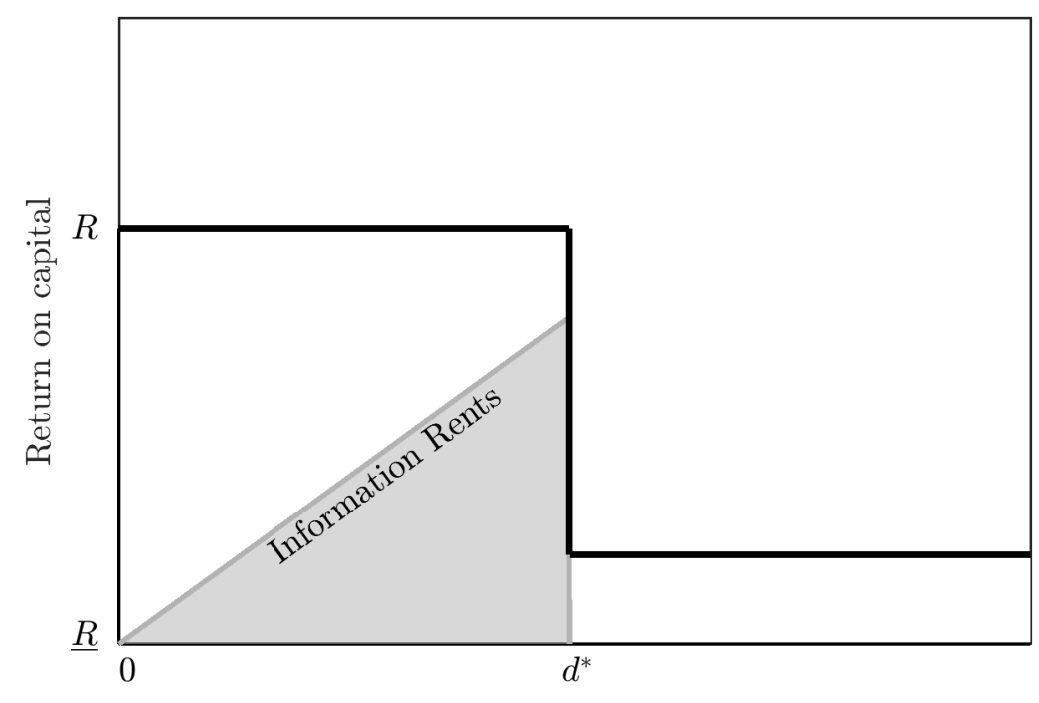

Default rate of risky project

Figure 2: Division of returns under asymmetric information. Black line is total return when $R$ is the first-best rate of return on capital. The gray area represents the information rents earned by risky firms and $r^{*}$ is the return on the outside option.

and the indivisibility of projects that prevents the bank from lending all funds to fewer but larger risky firms. Figure 2 shows the information rents increasing in the default rate. When this reaches $d^{*}$, the lender will optimally ration credit to safe firms because this allows them to raise risky lending rates. In this situation, a reduced portion of capital is allocated to productive projects and so results in sharp falls in productivity. This result helps rationalize evidence on whom credit tightening is concentrated. While lenders tighten credit standards during downturns, a puzzling feature of these episodes is that, conditional on observables, loan rejection rates increase more for lower-risk small businesses than higher-risk small business. ${ }^{7}$

Consider how our model differs from other models of credit rationing, such as Stiglitz and Weiss (1981). Although using the Stiglitz and Weiss (1981) model as a starting point, in their basic model, lenders only screen using the interest rate, implying a pooling equilibrium as there can only be one contract. In this case, rationing occurs as the lenders optimally set the interest rate above the expected return of some firms: if the interest rate is low, the lender will earn a small share of total return, but if it is too high, many safer firms will be excluded, increasing risk and reducing overall returns. As borrowers in Stiglitz and Weiss (1981) can choose projects, this result is partly due to a moral hazard dimension that we abstract from. In our paper, lenders can separate borrowers, causing the model dynamics and non-linearities to depend critically on

\footnotetext{
${ }^{7}$ As found, for example, by Armstrong et al. (2013) using U.K. data covering the recent financial crisis.
} 


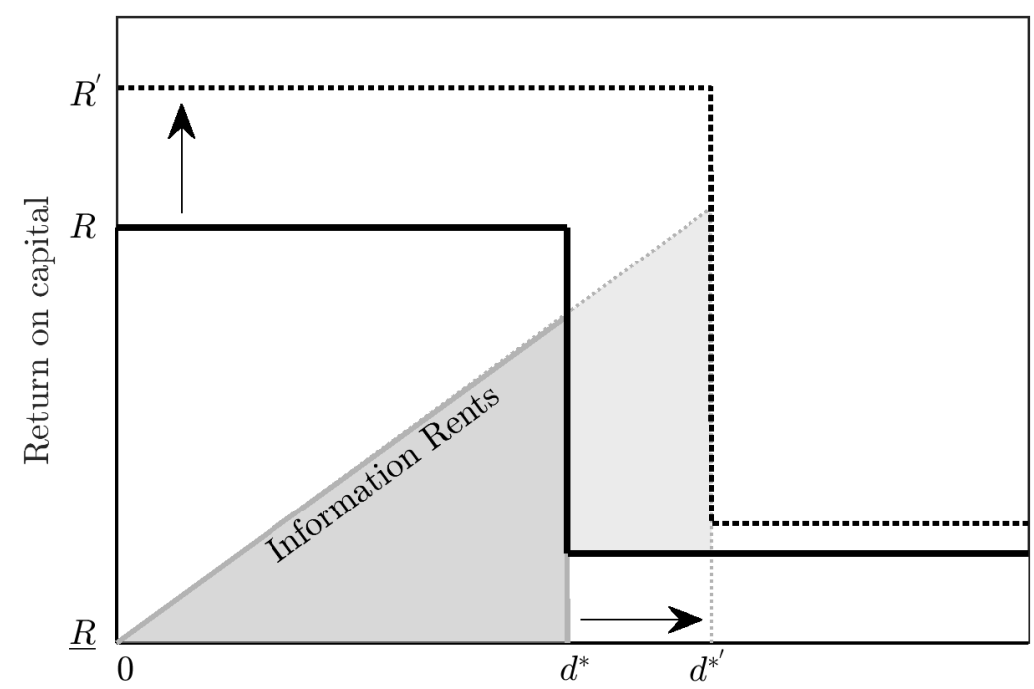

Default rate of risky project

Figure 3: Division of returns under asymmetric information under alternate first-best rates of return on capital.

the information rents. Furthermore, as highlighted in figure 3, financial instability falls in the interest rate in our model. Because the rents depend on the default rate rather than the interest rate level, when the return on capital rises, $d^{*}$ shifts out. $^{8}$

The Stiglitz and Weiss $(1981 ; 1992)$ model has been extended in several studies, including Bester (1985), Mankiw (1986), Williamson (1986), De Meza and Webb (1987), Besanko and Thakor (1987) and House (2006). These papers draw focus on stationary equilibria, whereas we are analyzing dynamic simulation and the mapping to business cycles. Figueroa and Leukhina (2018) present a model in which adverse selection can drive movements in productivity; however, as with the other studies mentioned above, this is caused by compositional effects in which the 'bad' types are less productive entrepreneurs. Reichlin and Siconolfi (1998) analyze a similar adverse selection problem in a stationary overlapping-generations model, finding it can generate persistent endogenous cycles. ${ }^{9}$ Our paper is also closely related to Kurlat (2013) and Benhabib et al. (2018).

\footnotetext{
${ }^{8}$ If there were a continuum of types rather than two, the vertical slope in figure 2 would be more shallow because firms rationed gradually according to their riskiness. It follows that financial instability is greater in a low interest rate environment and the proportion of risky assets in the economy higher. This is supported by data (see, e.g., Lian et al., 2018), but contrary to conventional models of adverse selection where the reverse is true (cf. Stiglitz and Weiss, 1981).

${ }^{9}$ Other recent research includes Martin (2009), who analyzes the relationship between entrepreneur wealth and investment under adverse selection; Guerrieri et al. (2010), who examine search equilibria with adverse selection (see also Williamson and Wright, 1994; Rocheteau, 2011; Lester et al., 2011; Chiu and Koeppl, 2016); Scheuer (2013), who analyzes business tax policy with adverse selection in credit markets and occupational choice;
} 
The former includes entrepreneurs that trade in assets to fund investment opportunities. As the entrepreneurs cannot separate the lemons, their presence introduces an interest spread. In our model, the screening of borrowers lies behind the fluctuations in TFP. Benhabib et al. (2018) also focus on pooling equilibria and analyze the presence of multiple equilibria introduced by the agency problem.

The model can help interpret several stylized empirical facts not explained by other models of financial frictions. First, the proposed model features occasional credit crunch episodes that introduce a negative skewness in investment that matches observed macroeconomic data. While infrequent credit crunches may have other sources, the focus in the literature is typically on intermediaries facing occasionally binding financing constraints (see, e.g., He and Krishnamurthy, 2013; Brunnermeier and Sannikov, 2014; Holden et al., 2019), rather than occasional credit tightening in the intermediary-firm relationship, as in this paper. Additionally, as discussed above, the credit friction can cause drops in aggregate productivity, whereas other models typically produce what appears as a tax on capital or investment. ${ }^{10}$ Although there is a recent literature mapping financial frictions to productivity, authors usually concentrate on the interaction between heterogeneity in productivity and some form of credit friction, such as collateral constraints (Jeong and Townsend, 2007; Buera and Shin, 2013; Moll, 2014), causing misallocation on the intensive margin whereby capital is not allocated to most productive firms (see also Pratap and Urrutia, 2012; Oberfield, 2013; Caggese and Cuñat, 2013; Gilchrist et al., 2013). ${ }^{11}$ In contrast, falls in productivity in this paper are largely driven by misallocation on the extensive margin as credit contracts sharply. The empirical evidence indicates that the extensive margin is important; for example, using U.K. bank data, Franklin et al. (2018) find that an aggregate credit supply shock of $10 \%$ leads to a fall in labour productivity of $5-8 \%$.

The model is described in detail in the next section before we outline some key analytical results in section 3. In section 4, we discuss some numerical results and the implications of the credit friction on financial instability and the macroeconomy. Finally, we summarize with some concluding remarks in section 5 .

Tomura (2012), who studies secondary capital market shut-downs caused by adverse selection; and Clementi and Hopenhayn (2006), who study the impact on firm behaviour of borrowing constraints that emerge from an asymmetric information problem.

${ }^{10}$ Movements in TFP play a central role in Kiyotaki and Moore (1997); however, the focus of research has since shifted from this channel.

${ }^{11}$ Banerjee and Moll (2010) do look at both the intensive and extensive margins of capital misallocation where the collateral constraints prevent efficient allocation; there is misallocation on the intensive margin when the marginal product of capital is unequal across entrepreneurs and on the extensive margin when there are entrepreneurs with no capital at all. The latter might occur due to entry costs, for example, and is likely to lead to much greater persistence in TFP fluctuations than misallocation on the intensive margin. 


\section{Model}

The model extends a standard real business cycle model by differentiating between three types of firm and assuming that each firm requires a fixed quantity of external finance to purchase $k$ units of capital. This assumption ensures that firms are reliant on outside funding. Because all firms require the same capital, the friction cannot be side-stepped by only funding a single, very large corporate firm. Every period, each firm draws a project characterized by a production technology, productivity level and a risk profile. In particular, the risk profile specifies the probability the project will fail, allowing no production. There are two types of project: one is more productive but risky and the other is less productive but safe. A proportion $\eta$ of firms have a perfectly observed project and so are suitable for raising funds via a bond market. The remaining $1-\eta$ firms have a privately observed project. Whereas a proportion $\lambda$ of these firms have no risk of default, the remaining $1-\lambda$ have a risky project that will only succeed with probability $p_{t}$. Throughout the paper, the former will be referred to as safe and the latter risky, and the firms with an observable project as corporates. Under a decentralized bond market, because all borrowers seek the same amount of finance, the only screening device to separate the risky and safe firms is the interest rate. In such an environment, either all firms will access funds at the same rate, or the safe firms will be rationed when the interest rate is set higher than their expected return, which might occur if default losses from risky loans are too high. We will show that the presence of non-corporates gives rise to a financial intermediation sector that can do better than a bond market by screening borrowers. That is, there exists a menu of contracts that safe and risky firms can self-select into, allowing lenders (banks henceforth) to identify their risk profile. We begin description of the model with the banking sector.

\section{$2.1 \quad$ Intermediaries}

The banks take deposits from households and extend loans to the firm sector. We assume the latter follows a two-stage game whereby lenders post contract offers that borrowers can choose to accept. ${ }^{12}$ This takes place in an anonymous spot market that leads to a sequence of static contracts, ${ }^{13}$ agreed at the end of period $t$, ahead of period $t+1$ production. In addition to

\footnotetext{
${ }^{12}$ Following, for example, Rothschild and Stiglitz (1976) and Wilson (1977). There are some consequences of the choice of sequence as discussed in Hellwig (1987); choosing a three-stage game, for instance, could lead to pooling or separating equilibria depending on the starting agent. However, based on what we observe in the data, the natural choice of agent to make the initial offer is the bank and allowing three stages would imply loan offers could be withdrawn once accepted. This is not something we observe in reality.

${ }^{13}$ Because firm-type is drawn every period, there is no process by which banks learn the firm type over time. During numerical simulations, we find that dynamic contracts are not Pareto improving in most states of the world.
} 
the interest rate, the lender introduces a lottery ${ }^{14}$ that allows the lender to set the probability of loan approval. As shown below, this will be the device that allows the lender to separate borrowers by designing incentive-compatible, or self-selecting, contracts. Specifically, the lenders post contracts $c_{t}^{i}=\left\{\tau_{t}^{i}, x_{t}^{i}\right\}$ for $i \in\{s, r\}$, where $\tau_{t}^{i}$ is the repayment rate, and $x_{t}^{i}$ the financing, or approval probability. We assume that the banks have access to a low-return technology, yielding return $r^{*}$ and implying that they need not lend all available funds. ${ }^{15}$

Letting $p_{t}^{i}$ and $R_{t}^{i}$ denote the success probability and gross rate of return on capital of a type- $i$ project respectively, and $\Lambda_{t, t+1}$ the stochastic discount factor, the lender must set contract terms subject to individual rationality (IR) constraints

$$
\mathbb{E}_{t}\left[\Lambda_{t, t+1} p_{t+1}^{i}\left(R_{t+1}^{i}-\tau_{t}^{i}\right)\right] \geq 0, \quad i=r, s
$$

which promise a weakly positive surplus to the firm, and subject to incentive compatibility (IC) constraints given by

$$
\mathbb{E}_{t}\left[\Lambda_{t, t+1} p_{t+1}^{i} x_{t}^{i}\left(R_{t+1}^{i}-\tau_{t}^{i}\right)\right] \geq \mathbb{E}_{t}\left[\Lambda_{t, t+1} p_{t+1}^{i} x_{t}^{j}\left(R_{t+1}^{i}-\tau_{t}^{i}\right)\right], \quad i, j=r, s ; i \neq j
$$

That is, the value to each borrower of declaring their type truthfully must be weakly greater than lying. As is standard in these mechanism design problems, and straightforward to prove, the problem can be simplified by dropping two constraints. The relevant constraints are the safe IR and the risky IC constraints, which further are found will be always binding as the objective function is increasing in the repayment rates. We can write these constraints as follows:

$$
\begin{gathered}
\mathbb{E}_{t}\left[\Lambda_{t, t+1}\right] \tau_{t}^{s}=\mathbb{E}_{t}\left[\Lambda_{t, t+1} R_{t+1}^{s}\right] \\
\mathbb{E}_{t}\left[\Lambda_{t, t+1} p_{t+1}\right] \tau_{t}^{r}=\mathbb{E}_{t}\left[\Lambda_{t, t+1} p_{t+1} R_{t+1}^{r}\right]-\mathbb{E}_{t}\left[\Lambda_{t, t+1} p_{t+1}\left(R_{t+1}^{r}-\tau_{t}^{s}\right)\right] \frac{x_{t}^{s}}{x_{t}^{r}} .
\end{gathered}
$$

It further follows from these constraints that $x_{t}^{r} \geq x_{t}^{s}$ (see Appendix C), so risky firms are always weakly more likely to be funded than safe projects. The intuition is that in order to pay higher repayment rates, the banks must offer a higher probability of being approved for finance. The banks solve

$$
\begin{aligned}
& \mathcal{V}\left(c_{t-1}^{s}, c_{t-1}^{r}\right)=\max _{c_{t}^{s}, c_{t}^{r}}\left\{\lambda x_{t-1}^{s}\left(\tau_{t-1}^{s}-r^{*}\right)+(1-\lambda) x_{t-1}^{r}\left(p_{t} \tau_{t-1}^{r}-r^{*}\right)+\mathbb{E}_{t}\left[\Lambda_{t, t+1} \mathcal{V}_{t+1}\left(c_{t}^{s}, c_{t}^{r}\right)\right]\right\} \\
& \text { s.t. } \quad 0 \leq x_{t}^{s} \leq x_{t}^{r} \leq 1 \\
& \quad \lambda x_{t}^{s}+(1-\lambda) x_{t}^{r} \leq \bar{x}_{t}
\end{aligned}
$$

and subject to constraints (2.3) and (2.4). The inequality constraint (2.5) is a feasibility constraint where $\bar{x}_{t} \leq 1$ is the maximum proportion of firm applications that can be approved. This

\footnotetext{
${ }^{14}$ See (Bolton and Dewatripont, 2005, pp. 59-60).

${ }^{15}$ This could be considered as a storage technology, a foreign or government bond, or some other lower-return asset.
} 
is determined in general equilibrium and will be less than one if the number of possible loans the bank can make is less than the number of firms seeking funds, in which case it is the ratio of the loan supply to the loan demand. When this ratio is greater than unity, $\bar{x}_{t}$ is bound at one. When constraint (2.5) is slack, rather than lending all available funds, banks invest a portion of their capital in a low-return asset or technology. Equations (2.3) and (2.4) allow $\tau_{t}^{r}$ and $\tau_{t}^{s}$ to be substituted out of the problem, leaving only $x_{t}^{r}$ and $x_{t}^{s}$ to be chosen. For these, the solution to the bank's problem gives

$$
\begin{aligned}
& \mathbb{E}_{t}\left[\Lambda_{t, t+1}\left(p_{t+1} R_{t+1}^{r}-r^{*}\right)\right]=\varrho_{t}-\psi_{t} \frac{1}{1-\lambda}+\varphi_{t}^{r} \frac{1}{1-\lambda} \\
& \mathbb{E}_{t}\left[\Lambda_{t, t+1}\left(\left(\lambda+(1-\lambda) p_{t+1}\right) R_{t+1}^{s}-r^{*}\right)\right]=\varrho_{t}+\varphi_{t}^{r}-\varphi_{t}^{s},
\end{aligned}
$$

where $\varrho_{t}$ is the Lagrange multiplier on the feasibility constraint, $\varphi_{t}^{s}$ and $\varphi_{t}^{r}$ those on $x_{t}^{s}$ and $1-x_{t}^{r}$ respectively, and $\psi_{t}$ is the Lagrange multiplier on $x_{t}^{r}-x_{t}^{s}$. These first-order conditions are also subject to Kuhn-Tucker conditions

$$
\begin{aligned}
& \varphi_{t}^{s} \geq 0 \\
& \varphi_{t}^{r} \geq 0 \\
& \varrho_{t} \geq 0 \\
& \psi_{t} \geq 0 \\
& \varphi_{t}^{s} x_{t}^{s}=0 \\
& \varphi_{t}^{r}\left(1-x_{t}^{r}\right)=0 \\
& \psi_{t}\left(x_{t}^{r}-x_{t}^{s}\right)=0 \\
& \varrho_{t}\left(\bar{x}_{t}-\lambda x_{t}^{s}-(1-\lambda) x_{t}^{r}\right)=0 .
\end{aligned}
$$

Due to the four inequality constraints, it is possible to identify four regimes that depend on parametrization and macroeconomic conditions, including pooling and separating equilibria, and the credit rationing of safe projects. A financial crisis, or credit crunch, will be characterized by banks storing a portion of available capital rather than using it to fund productive firms. Analysis of these regimes is given in section 3 below. We turn now to the firm sector.

\section{$2.2 \quad$ Firms}

When firms draw their type at the end of the period, they apply for external finance for which they may or may not be successful; if firms are successful in securing funds, they purchase $k$ units of capital ready for production in the following period, otherwise we assume they must exit. Of the funded risky projects, a proportion $1-p_{t}$ will fail before production begins. Success probability $p_{t} \in[0,1]$ follows the $\operatorname{AR}(1)$ process:

$$
p_{t}=\left(1-\rho_{p}\right) \bar{p}+\rho_{p} p_{t-1}+\varepsilon_{p, t} .
$$


If the firm fails, then the capital is lost completely. Let firm type be denoted $i \in\{c, s, r\}$ for corporates, safe and risky firms respectively. A successful funded project requires $k$ units of capital that is converted into $\omega_{t}^{i} k$ productive units, where we assume $\omega_{t}^{r}>\omega_{t}^{c}=\omega_{t}^{s}=1$. The firm hires $h_{t}\left(\omega_{t}^{i}\right)$ units of labour and produces output using

$$
y_{t}\left(\omega_{t}^{i}\right)=z_{t}\left[\omega_{t}^{i} k\right]^{\alpha}\left[h_{t}\left(\omega_{t}^{i}\right)\right]^{1-\alpha},
$$

where aggregate technology $z_{t}$ follows the stationary stochastic process:

$$
z_{t}=\rho_{z} z_{t-1}+\varepsilon_{z, t}
$$

Capital depreciates at $\delta$, so although a fixed input $k$ is required for production, the capital remaining after production will be $\omega_{t}^{i}(1-\delta) k$. The value of a successful funded type- $i$ firm can therefore be written

$$
V_{t}^{i}=\max _{h_{t}\left(\omega_{t}^{i}\right)}\left\{y_{t}\left(\omega_{t}^{i}\right)-W_{t} h_{t}\left(\omega_{t}^{i}\right)-\left(\tau_{t-1}^{i}-(1-\delta) \omega_{t}^{i}\right) k+V_{t}\right\}
$$

where $W_{t}$ is the market wage rate and $V_{t}$ the ex ante value of a firm, prior to drawing its type, given by

$$
V_{t}=\mathbb{E}_{t}\left[\Lambda_{t, t+1}\left(\eta V_{t+1}^{c}+(1-\eta)\left(\lambda x_{t}^{s} V_{t+1}^{s}+(1-\lambda) x_{t}^{r} p_{t+1}^{r} V_{t+1}^{r}\right)\right)\right] .
$$

The solution to the firm labour demand implies the real wage will equal the marginal product of labour for all firms

$$
W_{t}=(1-\alpha) \frac{y_{t}\left(\omega_{t}^{i}\right)}{h_{t}\left(\omega_{t}^{i}\right)}
$$

where it follows that output per worker $y_{t}^{i} / h_{t}^{i}$ and the efficiency capital-labour ratio $\omega_{t}^{i} k / h_{t}^{i}$ will be equal across all firms, using superscripts for convenience. We can then write the gross return on capital used in the previous section as

$$
R_{t}^{i} \equiv \alpha \frac{y_{t}^{i}}{k}+(1-\delta) \omega_{t}^{i}
$$

where the total surplus is $\left(R_{t}^{i}-\tau_{t-1}^{i}\right) k$ and noting that the gross return on efficiency units of capital, $\alpha \frac{y_{t}\left(\omega_{t}^{i}\right)}{\omega_{t}^{i} k}+(1-\delta)$, is equal for all firms. It follows that $R_{t}^{r}=\omega_{t}^{r} R_{t}^{c}=\omega_{t}^{r} R_{t}^{s}$.

As firms can make profits in equilibrium, in the absence of costs of entry, new firms would enter until it is possible for banks to allocate all funds to risky firms, charging a higher lending rate and excluding the safe firms entirely. ${ }^{16}$ To prevent this, we introduce a small fixed cost of entry.

\footnotetext{
${ }^{16}$ To see this, suppose a bank has sufficient funds to only lend to one type of firm. Without asymmetric information, the bank would be indifferent between lending to risky or safe firms as the net present value is equal. With asymmetric information, because the risky firms earn information rents, the banks prefer to either (i) lend only to safe firms, or (ii) lend only to risky firms because no information rents would need to be paid. Because risky firms can pretend to be safe, (i) is never possible.
} 
Any unfunded firms will be liquidated and must repay the entry costs to operate in the period that follows. To pay the entry costs, firms sell equity to households. Under this assumption, new firms will enter until the expected discounted profits $V_{t}$, given by equation (2.20), equals an exogenous fixed cost $F$. This condition is verified in the solution to the household problem, which we turn to now.

\subsection{Households}

The representative household faces the usual labour supply and consumption-savings decision, but with an additional portfolio choice problem. The household can choose to either deposit savings $S_{t}$ at a bank, purchase bonds, $B_{t}$, or purchase equity in new firms, $E_{t}$, to solve

$$
\max _{\substack{C_{t+s}, H_{t+s} \\ S_{t+s}, B_{t+s}, f_{t+s}}} \mathbb{E}_{t} \sum_{s=0}^{\infty} \beta^{t+s} U\left(C_{t+s}, H_{t+s}\right),
$$

subject to

$$
C_{t}+S_{t}+B_{t}+E_{t}\left(f_{t}, f_{t-1}\right)=R_{t-1} S_{t-1}+R_{t-1}^{B} B_{t-1}+W_{t} H_{t}-T_{t}+\Pi_{t}\left(f_{t}\right)
$$

where $R_{t}$ and $R_{t}^{B}$ are the interest earned on savings and bonds respectively, $f_{t}$ is the end-ofperiod mass of firms in the economy, $\Pi_{t}$ are profits from the household-owned banks and payoffs from equity holdings, and $T_{t}$ is lump-sum taxes. The household consumption-savings decision and portfolio allocation is characterized by

$$
1=\mathbb{E}_{t}\left[\Lambda_{t, t+1}\right] R_{t},
$$

where $\Lambda_{t, t+1}=\beta \frac{U^{\prime}\left(C_{t+1}\right)}{U_{t}^{\prime}\left(C_{t}\right)}$, and with $R_{t}^{B}=R_{t}$. Labour supply is determined by

$$
W_{t}=-\frac{U^{\prime}\left(H_{t}\right)}{U_{t}^{\prime}\left(C_{t}\right)}
$$

The amount of equity purchased, $E_{t}$, corresponds to the fixed costs paid for new entrants and is a claim on future profit streams of the new firms. The number of new entrants at $t$ is the difference between the number of firms in $t$ and the non-exiting firms in $t-1$. It follows that expenditure on equity is given by

$$
E_{t}=\left(f_{t}-\left(\eta+(1-\eta)\left(\lambda x_{t-1}^{s}+(1-\lambda) x_{t-1}^{r}\right)\right) f_{t-1}\right) k F .
$$

Using the return on capital given in equation (2.22), the total profits earned by the firms per unit $k$ given as the sum of the information rents received by risky firms and profits received by corporates can be written

$$
\pi_{t}=(1-\eta)(1-\lambda) p_{t} x_{t-1}^{s}\left(R_{t}^{r}-R_{t}^{s}\right)+\eta\left(R_{t}^{s}-R_{t-1}\right) .
$$


Using these, the choice of the number of new firms to finance gives the first-order condition

$$
F=\mathbb{E}_{t}\left[\Lambda_{t, t+1}\left(\left(\eta+(1-\eta)\left(\lambda x_{t}^{s}+(1-\lambda) x_{t}^{r}\right)\right) F+\pi_{t+1}\right)\right]
$$

which, using equations (2.19) and (2.20), implies the entry condition $V_{t}=F$. That is, the households will fund new firms until the present value of future profits equals the cost of entry. We can also define the ex post gross rate of return to banks as

$$
R_{t}^{L}=r^{*}+\left(\lambda x_{t-1}^{s}\left(\tau_{t-1}^{s}-r^{*}\right)+(1-\lambda) x_{t-1}^{r}\left(p_{t} \tau_{t-1}^{r}-r^{*}\right)\right) \frac{1}{\phi_{t-1}} .
$$

$\phi_{t} \equiv \frac{S_{t}}{(1-\eta) f_{t} k}$ is the loan supply-demand ratio where $(1-\eta) f_{t} k$ is the capital sought by firms, and $S_{t}$ the household savings that the bank is intermediating. Free-entry in the banking sector then implies the zero-arbitrage condition must hold:

$$
1=\mathbb{E}_{t}\left[\Lambda_{t, t+1} R_{t+1}^{L}\right] .
$$

Given that bank liabilities are risk-free deposits but assets are risky loans, it is possible for there to be ex post profits or losses in equilibrium. When there are profits, the household will receive a dividend, bailing out the banks when there are losses. Finally, it is assumed that the household utility function is in the form proposed in King et al. (1988):

$$
U\left(C_{t}, H_{t}\right)=\frac{\left(C_{t}^{1-\chi}\left(1-H_{t}\right)^{\chi}\right)^{1-\sigma}}{1-\sigma} .
$$

\subsection{Market clearing and aggregation}

Labour market clearing implies that total labour demanded by the three types of firm will equal the labour supplied by households, $H_{t}$. An equal efficiency-capital-labour ratio follows from the perfect labour market and so, defining the aggregate efficiency capital as

$$
\hat{K}_{t} \equiv\left[\eta+(1-\eta)\left(\lambda x_{t-1}^{s}+(1-\lambda) x_{t-1}^{r} p_{t}^{r} \omega_{t}^{r}\right)\right] k f_{t-1},
$$

we can write the aggregate labour demand equation

$$
W_{t}=(1-\alpha) z_{t}\left(\frac{\hat{K}_{t}}{H_{t}}\right)^{\alpha}
$$

We can likewise give aggregate output as $Y_{t}=z_{t} \hat{K}_{t-1}^{\alpha} H_{t}^{1-\alpha}$, or rather, with aggregate productivity defined as a function of the ratio of efficiency-capital to total capital stock:

$$
A_{t}=z_{t}\left(\frac{\hat{K}_{t}}{K_{t-1}}\right)^{\alpha},
$$


with the familiar looking aggregate production function

$$
Y_{t}=A_{t} K_{t}^{\alpha} H_{t}^{1-\alpha}
$$

that follows. Finally, we close the model with an aggregate resource constraint

$$
Y_{t}=C_{t}+I_{t}
$$

where investment is the difference between the new capital stock, $K_{t}$, and the sum of the depreciated returned capital and the undepreciated, unused capital

$$
I_{t}=K_{t}-K_{t-1}+\delta \hat{K}_{t}-(1-\eta)(1-\lambda) x_{t-1}^{r}\left(p_{t}^{r} \omega_{t}^{r}-1\right) k f_{t-1} .
$$

\section{Analytical results}

The menu of contracts implied by the set of inequality constraints in equations (2.8)-(2.15) on offer at time $t$ can be characterized as belonging to several regimes that depend on the risk and rate of return of each project. In the subsequent theoretical and numerical analysis, we consider the role of risk by fixing the risky firm productivity $\omega_{t}^{r}=1 / p_{t}$ so the value of each firm is equal in the first-best economy. It follows that a shock to $p_{t}$ is a risk shock. We will draw attention to two key regimes of interest: a full-lending regime and a capital-misallocation regime.

Definition 1 (Full-lending regime) Under this regime, banks intermediate all available funds so $\lambda x_{t}^{s}+(1-\lambda) x_{t}^{r}=\bar{x}_{t}$.

Definition 2 (Capital-misallocation regime) Under this regime, banks do not intermediate all available funds, so $\lambda x_{t}^{s}+(1-\lambda) x_{t}^{r}<\bar{x}_{t}$. Instead, banks use the low-return technology for a proportion of their available funds.

As banks restrict total lending, capital-misallocation is on the extensive margin as opposed to the intensive margin, whereby funds would be inefficiently allocated across projects of differing productivities. By assuming $\omega_{t}^{r}=1 / p_{t}$, we are drawing focus on the margin of interest. We can think of this misallocation as representing a credit crunch or financial crisis. In the numerical analysis discussed below, we find this to be an occasional, relatively short-lived phenomenon, much as we observe in the data.

Proposition 1 If $\omega_{t}^{r}=1 / p_{t} \forall t, \bar{x}_{t}>1-\lambda$, and $R_{t} \geq r^{*}$, then banks will choose $x_{t}^{s} \leq x_{t}^{r}=1$.

Proposition 1 highlights that the contract outcomes simplify when only considering the role of risk. ${ }^{17}$ In particular, if $\omega_{t}^{r}=1 / p_{t}$, a pooling equilibrium is ruled out except for when $\bar{x}_{t}=1 .{ }^{18}$

\footnotetext{
${ }^{17}$ Proofs given in Appendix D.

${ }^{18}$ In fact, the pooling constraint, $x_{t}^{r}-x_{t}^{s} \geq 0$, can no longer bind because, even when $x_{t}^{r}=x_{t}^{s}=1$, the lender is
} 
However, under our model calibrations, pooling rarely occurs in numerical simulations. To see why, suppose that household saving increases such that all firms looking for funds could receive them (that is, $\bar{x}_{t}$ increases to 1 ) and suppose a single non-separating contract was on offer. Given these conditions, because the lender absorbs all default losses, successful risky firms will earn higher profits as their repayment rate falls. This increase in the return on equity will encourage higher firm entry. As more firms enter, $\bar{x}_{t}$ falls, causing $x_{t}^{s}$ to fall, reducing the information rents and the value of equity. As well as keeping $\bar{x}_{t}$ from the upper abound, these competing forces prevent $\bar{x}_{t}$ from falling low. Indeed, it follows the condition $\bar{x}_{t}>1-\lambda$ required in proposition 1 always holds in our numerical simulations under empirically plausible parameterizations. ${ }^{19}$ Let us consider the two regimes of interest.

Corollary 1 There is a threshold expected default rate, $d_{t}^{*}=\mathbb{E}_{t}\left[1-p_{t+1}^{*}\right]$, that satisfies

$$
\mathbb{E}_{t}\left[\Lambda_{t, t+1} p_{t+1}^{*} R_{t+1}^{s}\right]=\mathbb{E}_{t}\left[\Lambda_{t, t+1}\left(R_{t+1}^{s}-\frac{\lambda}{1-\lambda}\left(R_{t+1}^{s}-r^{*}\right)\right)\right]
$$

whereby the economy will be in the full-lending regime when $\mathbb{E}_{t}\left[1-p_{t+1}\right] \leq d_{t}^{*}$ and the capitalmisallocation regime when $\mathbb{E}_{t}\left[1-p_{t+1}\right]>d_{t}^{*}$.

Proposition 2 The threshold expected default rate, $d_{t}^{*}$, rises in the interest rate.

The point at which the economy switches regimes occurs when the expected default rate of risky projects rises above the threshold $d_{t}^{*}$. This is found by combining the first-order conditions (2.6) into (2.7) and finding the point at which $\varrho_{t}$, the Lagrange multiplier on the feasibility constraint, equals zero. In the deterministic case, we can state, more succinctly, that if the expected default rate

$$
d_{t}>\frac{\lambda}{1-\lambda}\left(1-\frac{r^{*}}{R_{t+1}^{s}}\right)
$$

then banks will restrict credit to safe firms. We can see that, conditional on $r^{*}$, $d_{t}^{*}$ depends positively on both the proportion of safe firms in the economy and on the return on capital. Proposition 2 follows given the link between the expected return to capital $\mathbb{E}_{t}\left[R_{t+1}^{s}\right]$ and the real interest rate, $R_{t}$.

When $d_{t}>d_{t}^{*}$, the lender stores capital rather than provide finance to all safe firms. This reduces the efficiency of the aggregate capital stock, as captured in equation (2.28), and so appears as a shock to aggregate productivity. In addition to this mechanism, we find that the information rents introduce a time-varying spread between the expected return to capital, $\mathbb{E}_{t}\left[R_{t+1}^{s}\right]$, and savings rate, $R_{t}$. While changes in risk will have no effect on the spread in the first-best economy,

indifferent between pooling and separating due to the linearity of the IC constraint. That is, an additional dollar earned by increasing the rate charged to risky borrowers is perfectly offset by a dollar lost when the number of loans is reduced by cutting $x_{t}^{s}$.

${ }^{19}$ In particular, this refers to observed share of risky loans on bank balance sheets. 
with hidden information, the risky firms earn higher rents when risk is greater, reducing the marginal efficiency of investment. In this way, the agency problem acts to increase the volatility of movements in the spread beyond what can be accounted for with evolutions in the default risk, linking our results to literature discussing the 'credit spread puzzle' (see Gilchrist and Zakrajšek, 2012). We note that this produces a counter-cyclical spread and can magnify the propagation of other shocks to the extent they effect default rates. We refer to these effects as the financial accelerator mechanism.

\subsection{Two Channels}

To draw comparison with the RBC model, we can identify two channels by which financial disturbances affect real macroeconomic outcomes. The first is an 'investment-wedge' channel, whereby the adverse selection affects the marginal efficiency of investment primarily through movements in the information rents. This inefficiency is measured by the spread between the savings rate and the risky return to capital which, using the average return on bank lending (2.26) and the firm lending rates (2.3)-(2.4), can be given by

$$
\Delta_{t} \equiv \mathbb{E}_{t}\left[(1-\lambda)\left(1-p_{t+1}\right) x_{t}^{s} R_{t+1}^{s}+\left(R_{t+1}^{s}-r^{*}\right)\left(\phi_{t}-\lambda x_{t}^{s}-(1-\lambda) x_{t}^{r}\right)\right] \frac{1}{\phi_{t}} .
$$

From this we can see that two factors contribute to this wedge: the information rents, measured by $(1-\lambda)\left(1-p_{t+1}\right) x_{t}^{s}$, and a capital misallocation effect in the second term. This misallocation occurs when banks use their low-return technology, rationing credit to borrowers, as the average rate of return on lending must fall relative to the return on capital. Recall that $\phi_{t}$ is the loan supply-demand ratio, so if all household savings are intermediated to firms, it follows that the condition $\phi_{t}=\bar{x}_{t}=\lambda x_{t}^{s}+(1-\lambda) x_{t}^{r}$ holds and this effect disappears. The information rents increase in the expected default rate, and because banks can only reduce them by lowering $x_{t}^{s}$ and rationing credit to safe firms, one can see that if the default rate increases sufficiently, the contribution of the misallocation effect will rise.

The second channel is the efficiency wedge, whereby the credit friction generates movements in total factor productivity during the capital-misallocation regime. From equation (2.29), this can be written

$$
A_{t}=z_{t}\left(\frac{\eta+(1-\eta)\left(\lambda x_{t-1}^{s}+(1-\lambda) x_{t-1}^{r}\right)}{\eta+(1-\eta) \phi_{t-1}}\right)^{\alpha} \leq z_{t} .
$$

If banks are intermediating all available funds, then, as before, $\phi_{t}=\bar{x}_{t}=\lambda x_{t}^{s}+(1-\lambda) x_{t}^{r}$, and TFP just depends on exogenous technology $z_{t}$. When the adverse selection problem for the bank increases, due to increased risky firm default, for example, then banks restrict credit to firms by reducing $x_{t}^{s}$ and $A_{t}$ falls. ${ }^{20}$

\footnotetext{
${ }^{20}$ There is another way that capital misallocation can occur: if there are fewer firms seeking funds than there
} 


\section{Numerical Analysis}

To provide an appropriate benchmark case, we use the same model with the information asymmetry removed. This first-best economy is analogous to a standard real business cycle model; absent the information problem, all firms can be considered equivalent to corporates, and so are able to raise funds in the bond market. Another version of the model is also considered in the analysis to assess the mapping from the credit friction to the interest spread and TFP. For this exercise, the real business cycle model is simulated with the fluctuations in the spread between the savings rate and the expected return to capital implied by the adverse selection economy. Because this introduces a wedge in the marginal efficiency of investment, we refer to this as the 'investment wedge' model; it allows us to effectively "switch off" the TFP channel. The exercise reinforces the results from the previous section: if one assumes the economy to be in the full-lending regime in steady state, in the region of the steady state, the credit friction only maps to fluctuations in the interest spread. This produces a financial accelerator mechanism that magnifies the effects of changes to default risk. Larger adverse shocks, however, can cause the economy to switch to a capital-misallocation regime in which lenders restrict credit, choosing to store capital rather than finance all safe projects. For instance, if the default rate of risky firms increases by around $3 \%$ from the ergodic mean, credit rationing occurs, and, through the lens of a real business cycle model, appears as a negative shock to TFP, dominating the effects of the investment wedge in all but the marginal cases.

\subsection{Parametrization and Calibration}

In addition to the parameters common to the real business cycle (RBC) literature, we are left with several parameters specific to the adverse selection economy. The size of firms is pinned down by the required capital, $k$; however, this has no effect on aggregate outcomes, and so we set $k=1$ without loss of generality. ${ }^{21}$ The share of corporate firms, $\eta$, is set to 0.5 in line with the proportion of employment at establishments with greater than 500 employees. ${ }^{22}$ We calibrate $\lambda=0.775, p=0.971$, and $F=0.149$ to target the proportion of risky bank loans, the mean firm entry rate, and the mean loan default rate. For the former, we target $24 \%$, which is the

is capital available, that is, $\phi_{t}>\bar{x}_{t}$, then banks must store surplus capital. However, these surplus funds reduce total return on lending but do not affect the information rents; it follows this misallocation never occurs in numerical simulations unless there is a negative real interest rate because households would rather choose to increase consumption.

${ }^{21}$ I.e., $k$ is just a normalization device. This follows from constant returns to scale in production. $k$ and $f_{t}$ only appear in the model multiplied together, so adjusting $k$ only implies a change in $f_{t}$ without affecting any other variable.

${ }^{22}$ The Statistics of U.S. Businesses (SUSB) considers establishments with fewer than 500 employees as small. According to the SUSB, the share of small business fell from over $54 \%$ in 1988 to under $47 \%$ in 2015 , with a mean of just over $50 \%$. 


\begin{tabular}{llll}
\hline Parameter & Description & Value & Target \\
\hline$\eta$ & Share of corporates & 0.5 & - \\
$\lambda$ & Non-corporate share of safe & 0.775 & $\mathbb{E} \frac{1-\lambda}{\bar{x}_{t}}=0.241$ \\
& firms & & \\
$p$ & Risky firm success rate & 0.971 & $\mathbb{E} \frac{(1-\lambda)\left(1-p_{t+1}\right)}{\bar{x}_{t}}=0.0069$ \\
$F$ & Firm entry cost & 0.149 & $\mathbb{E}(1-\eta)\left(1-\lambda x_{t}^{s}-(1-\lambda) x_{t}^{r}\right)=0.125$ \\
\hline
\end{tabular}

Table 1: Calibrations of adverse selection model parameters.

average share of bank loans classified as 'acceptable risk' over the interval 1997Q2-2017Q2.. ${ }^{23}$ For the latter, we target a value of $2.8 \%$ per annum, taken from the average delinquency rate on commercial and industrial loans over the period 1987Q1-2017Q1. ${ }^{24}$ Finally, we target a mean annual firm entry rate of $12.5 \%$ in line with the average entry of U.S. establishments over the period $1977-2014 .{ }^{25}$ We set $r^{*}$ to 1 so the low-return asset is a storage technology. ${ }^{26}$

These calibrations are listed in table 1. For the remaining parameters, we closely follow the RBC literature. The capital share of output $\alpha=0.3$; capital depreciates at $\delta=2.3 \%$ per quarter; and the household discount factor $\beta=0.99$. The utility weight on leisure, $\chi=0.64$ to target a steady-state labour supply $H=1 / 3$, and the intertemporal elasticity of substitution, $\sigma=2$. These are all shown in table 2 . We calibrate the shock processes using a simulated method of moments approach; some further detail is given in the next section.

\subsection{Simulations}

We compute a second-order pruned perturbation approximation to the model and impose the inequality constraints following the algorithm of Holden (2016). ${ }^{27}$ We draw comparison to the

\footnotetext{
${ }^{23}$ The interval includes all observations in the time series. Source: BGFRS, Total Value of Loans for All Commercial and Industry Loans, Other Risk (Acceptable), All Commercial Banks [EVAONQ], retrieved from FRED, Federal Reserve Bank of St. Louis; https://fred.stlouisfed.org/series/EVANQ, November 27, 2017; and Total Value of Loans for All Commercial and Industry Loans, All Commercial Banks [EVANQ], retrieved from FRED, Federal Reserve Bank of St. Louis; https://fred.stlouisfed.org/series/EVANQ, November 27, 2017.

${ }^{24}$ The interval includes all observations in the time series. Source: BGFRS, Delinquency Rate on Commercial and Industrial Loans, All Commercial Banks [DRBLACBS], retrieved from FRED, Federal Reserve Bank of St. Louis; https://fred.stlouisfed.org/series/DRBLACBS, September 4, 2016.

${ }^{25}$ The interval includes all observations in the time series. Source: The Longitudinal Business Database, Center for Economic Studies, U.S. Census Bureau (collected November 2017 from https://www.census.gov/ces/dataproducts/bds/data.html).

${ }^{26}$ This technology can represent bank excess reserves, which often increase sharply during downturns. See figure 12 in appendix B.

${ }^{27}$ The algorithm extends Dynare (Adjemian et al., 2011) to solve models featuring inequality constraints. Following the basic algorithm of Holden (2016), we treat the constraints in a perfect-foresight manner. That
} 


\begin{tabular}{lll}
\hline Parameter & Description & Value \\
\hline$\alpha$ & Capital share of production & 0.3 \\
$\beta$ & Household discount factor & 0.99 \\
$\delta$ & Capital depreciation rate & 0.023 \\
$\sigma$ & Intertemporal elasticity of substitution & 2 \\
$\chi$ & Utility share of labour & 0.642 \\
\hline
\end{tabular}

Table 2: Parametrisation of common real business cycle parameters.

first-best economy, which is equivalent to the standard RBC model. ${ }^{28}$ To calibrate the persistence parameter, we estimate an autoregression of TFP with a linear trend ${ }^{29}$ finding $\rho_{z}=0.978$. The remaining parameters controlling the shock processes are calibrated to target second moments and cross-correlations. The standard deviation of the technology shock was calibrated to $\sigma_{a}=$ $0.00619,{ }^{30}$ while the standard deviation and persistence of the risk shock were calibrated to $\sigma_{p}=0.00633$ and $\rho_{p}=0.800$ respectively. ${ }^{31}$ We did initially include a shock to the relative value of risky projects, but this was calibrated to zero.

\subsubsection{Unconditional Moments}

To gain some insight into the empirical performance of the model as compared to the financially efficient model, we report simulated and empirical moments in table 3. The model does well at matching the observed skewness in output and investment despite not being targeted in the calibration. Including the risk shock reduces the procyclicality of consumption and leads to a negative correlation between the interest spread and output. Although a countercyclical response of consumption might seem to count against the model set-up, the response is non-monotonic; for risk shocks large enough to cause financial crisis, because the mechanism maps to a decline in TFP, consumption can fall, as it would in the RBC model with a negative technology shock. The simulated moments reflect that the risk shock has no effect on the RBC model. Furthermore,

is, we approximate by assuming that the model's agents act today as if they were certain in which future periods the constraint would be binding. Having experimented with more accurate simulations that do not make this perfect-foresight approximation, we found quantitatively similar results, suggesting that the precautionary effects associated with the bound are not overly important. However, performing calibration and producing average impulse responses at this higher level of accuracy are computationally difficult. Thus, for consistency we treat the bound in this perfect-foresight manner throughout. However, since we have a second-order solution to the underlying model, we will still capture precautionary effects stemming from the model's other non-linearities.

${ }^{28}$ First-best and RBC are used interchangeably.

${ }^{29}$ Employing the series of TFP constructed by Fernald (2014), which accounts for variable utilization.

${ }^{30} \sigma_{a}=0.00686$ in the RBC model.

${ }^{31}$ The risk shock has no effect in the RBC model and so is ignored. 


\begin{tabular}{lcccc}
\hline & & U.S. Data & RBC & AS \\
\hline \multirow{4}{*}{ Standard Deviation } & $I$ & 4.515 & 3.228 & 4.588 \\
& $C$ & 0.917 & 0.555 & 0.582 \\
& $\Delta$ & 0.178 & 0 & 0.177 \\
\hline \multirow{3}{*}{ Skewness } & $Y$ & -0.240 & 0.068 & -0.278 \\
& $I$ & -0.606 & -0.042 & -0.626 \\
& $C$ & -0.315 & 0.117 & 0.197 \\
& $\Delta$ & 1.671 & - & 0.073 \\
\hline \multirow{3}{*}{ Correlaton $w / Y$} & $I$ & 0.882 & 0.994 & 0.907 \\
& $C$ & 0.879 & 0.987 & 0.723 \\
& $\Delta$ & -0.392 & - & -0.221 \\
\hline
\end{tabular}

Table 3: Simulated and empirical moments. Data for $Y, I$ and $C$ is HP-filtered U.S. time series 1983Q22016Q2; investment wedge, $\Delta$, is the spread between Moody's BAA-rated corporate bond yields and 10-Year Treasury Constant Maturity. Simulated time series of $Y, I$ and $C$ are HP-filtered. Standard deviations are in percent for $Y, I$ and $C$ and percentage points for $\Delta$.

although not targets in the calibration, the mean and standard deviation of the spread between the average rate of return on capital and the risk-free rate, $\Delta_{t}$, is 0.64 and 0.177 percentage points, respectively. This is close to 0.57 and 0.178 percentage points, which are the observed first and second moments of the spread between Moody's BAA corporate bond and 10-year Treasury bond yields. ${ }^{32}$

\subsubsection{Impulse Response Functions}

We now turn to the analysis of the propagation of the risk shock, which is an exogenous increase in the default rate of risky firms, caused by a decline in the success probability, $p_{t} \cdot{ }^{33}$ The central result is that risk matters as a first-order issue. While the disturbance generates economic fluctuations in our model, the value of projects remain equal under symmetric information because $\omega_{t}=1 / p_{t}$, leaving the first-best economy unaffected. Whereas without hidden information, the only important factor regarding firm finance is the expected discounted value, with adverse selection, the increased risk leads to higher information rents and so an increase in the investment wedge. Figure 4 shows impulse response functions to a 1 standard deviation risk shock, that is, an increase in the default rate of 0.63 percentage points. By widening the investment wedge,

\footnotetext{
${ }^{32}$ Data used is since 1971 - the average spread is slightly lower over the entire available time series. This spread is often used as a proxy for the investment wedge (see, e.g., Christiano et al., 2014).

${ }^{33} \mathrm{We}$ discuss the propagation of a positive transitory technology shock in Appendix A. We leave this from here as there is little difference from the RBC model.
} 

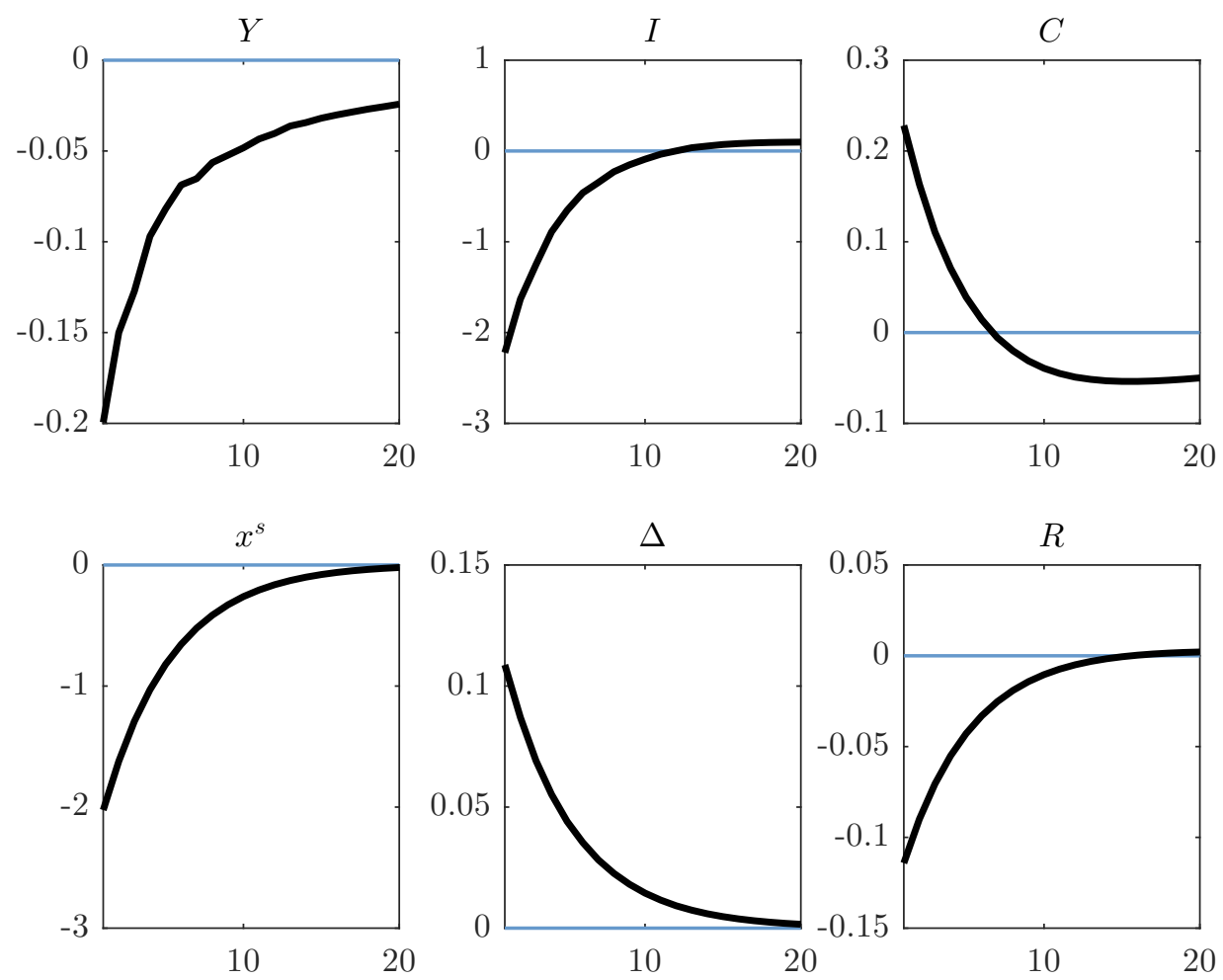

Figure 4: Impulse response functions to a 1 standard deviation (s.d.) transitory risk shock. Time is quarterly, and plots show percentage deviation from ergodic mean for $Y, I$ and $C$, and percentage point deviation for $x^{s}, \Delta$ and $R$.

the increased default rate leads to a sharp $2 \%$ downturn in investment. Facing a lower interest rate, households substitute investment for consumption, dampening the overall fall in aggregate demand, which only shrinks by $0.2 \%$. The share of risky loans increases as banks reduce funding to safe firms, allowing the banks to charge risky borrowers a higher repayment rate, $\tau^{r}$.

Figure 5 shows expected impulse responses found by increasing the shock to reach the default threshold, $d_{t}^{*}$. In this case, the probability of risky firm default increases by 3 percentage points, and, due to higher information rents, leads to banks rationing credit to safe firms to charge risky firms higher repayment rates. While the proportion of safe firms that are approved for loans, $x^{s}$, falls in both figures 4 and 5 , the former is a general equilibrium result caused by the fall in household saving being greater than the fall in firm numbers, whereas the latter is due, in part, to banks being unwilling to lend all available funds. This leads to a sharp decline in TFP and much sharper contractions in investment and output. Figure 5 also plots a version of the model with the TFP channel "switched off." This allows us to assess the relative contribution from the endogenous variation in the investment wedge and TFP. For smaller shocks, as in figure 4, the financial friction is affecting the real economy via the investment wedge, whereas for larger 

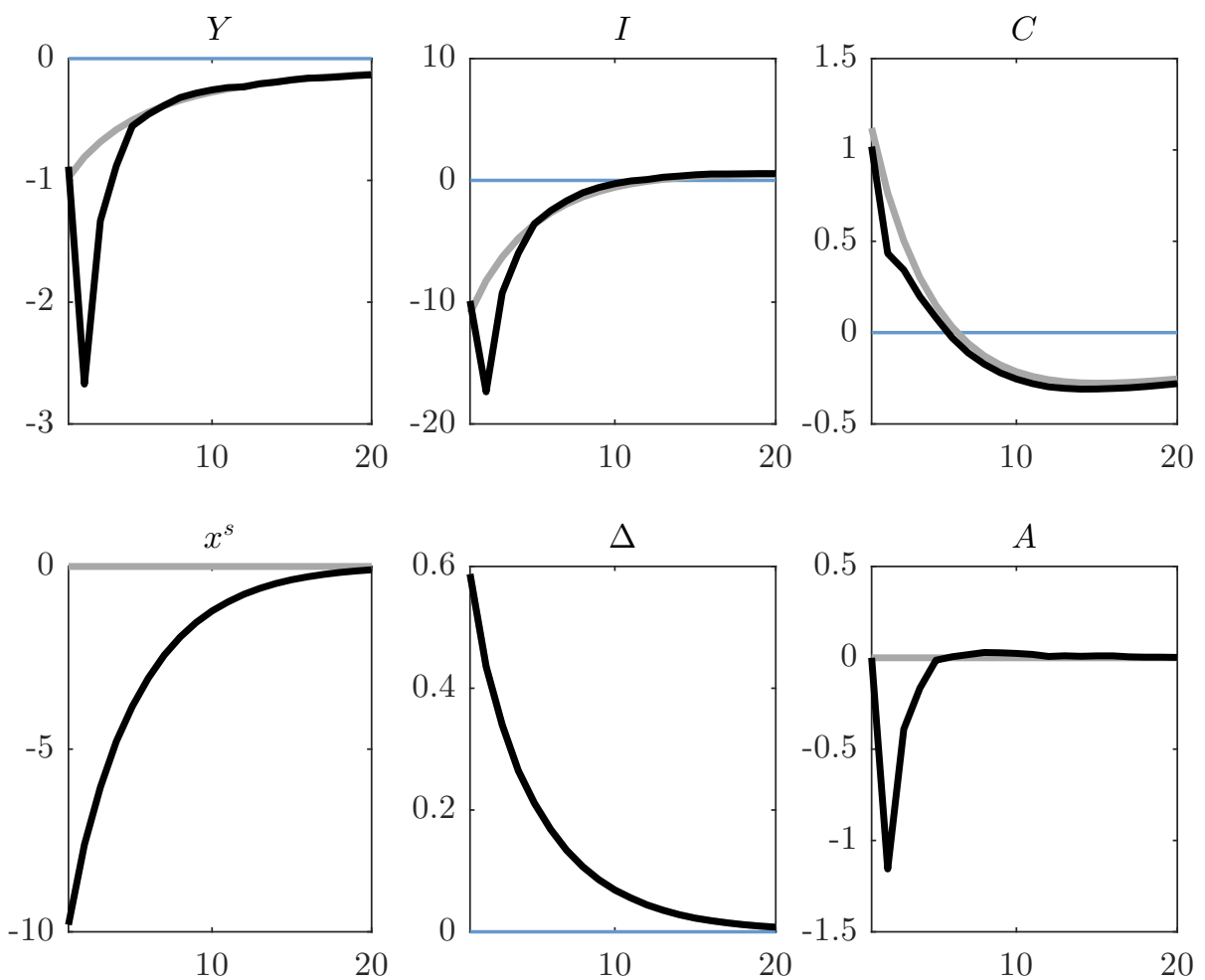

Figure 5: Impulse response functions to a transitory risk shock of 3 percentage points comparing our model (black line) with a version with the TFP "switched off" (gray line). Time is quarterly, and plots show percentage deviation from ergodic mean for $Y, I, C$ and $A$, and percent point deviation for $x^{s}$ and $\Delta$.

shocks, fluctuations can be mapped to both the investment wedge and TFP.

In this framework, the focus is on supply-side frictions. To model episodes such as the 200709 recession, it is necessary to add an exogenous demand-side disturbance. In figure 6, we plot expected impulse response functions to a combination of the risk shock and a negative demand shock. For the latter, we employ an unexpected increase in $\beta$ of $0.0015 .^{34}$ The time preference shock occurs simultaneously with a $4.1 \%$ shock to risky firm default. ${ }^{35}$ The financial friction affects real outcomes via the same channels just discussed. Quantitatively, the crisis experiment can capture much of the observed movements in 2008. In the U.K., for example, between 2008Q1 and 2009Q2, new loans to SMEs fell by 21\%, real GDP fell by 6.13\%, real

\footnotetext{
${ }^{34}$ This shock follows an $\operatorname{AR}(1)$ process with persistence parameter equal to 0.99 . If the change were completely persistent, this would be equivalent to a change in the steady-state interest rate from $4 \%$ to $3.5 \%$.

${ }^{35}$ Although we abstract from the sources of default risk, likely to arise largely from balance sheet factors and an interaction with reduced demand, the shock captures the impact of these factors on bank lending and seems a natural choice of shock to include. The choice of demand shock follows much recent literature to generate large falls in demand (see, e.g., Fernández-Villaverde et al., 2015; Aruoba et al., 2018).
} 

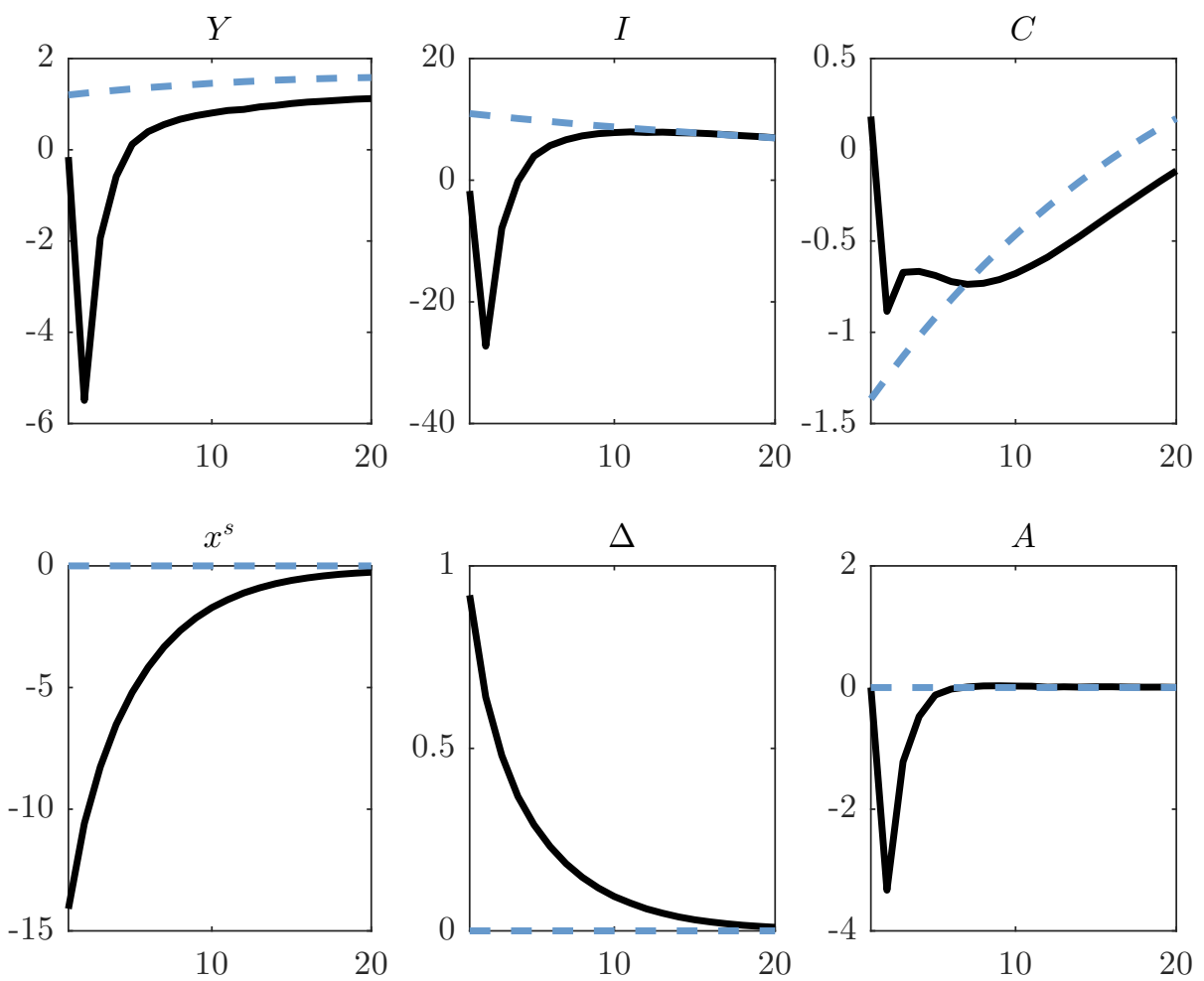

Figure 6: Impulse response functions to a simultaneous time-preference shock and risk shock comparing our model (black line) with the RBC model (blue dashed). Time is quarterly, and plots show percentage deviation from ergodic mean for $Y, I, C$ and $A$, and percentage point deviation for $x^{s}$ and $\Delta$.

investment by $21.8 \%$, and real consumption by $5.89 \%{ }^{36}$ With the exception of consumption, the magnitudes of responses shown in figure 6 are close to that in the data. Furthermore, the $3.3 \%$ decline in TFP closely matches that of the OECD measure of multifactor productivity for the U.K. over the same period, found to be $3.24 \% .{ }^{37}$ Note that given the size of the contraction in investment, without the sharp fall in TFP, it would not be possible to generate the size of the decline in output. Other papers employ shortcuts to account for this issue, including exogenous TFP shocks (e.g., Christiano et al., 2015) and capital quality shocks (e.g., Gertler and Kiyotaki, 2010).

\footnotetext{
${ }^{36}$ Data on lending from OECD, Financing SMEs and Entrepreneurs: An OECD Scoreboard, "New business lending, SMEs", 2008-2009, retrieved on November 14, 2017 (http://stats.oecd.org/). Remaining data retrieved from FRED, Federal Reserve Bank of St. Louis on December 11, 2017. GDP: Eurostat, Real Gross Domestic Product for United Kingdom [CLVMNACSCAB1GQUK] (https://fred.stlouisfed.org/series/CLVMNACSCAB1GQUK). Investment: Bank of England, Real Investment Expenditures in the United Kingdom [RIVEXUKQ] (https: //fred.stlouisfed.org/series/RIVEXUKQ). Consumption: Bank of England, Real Consumption Expenditures in the United Kingdom [RLCMEXUKQ] (https://fred.stlouisfed.org/series/RLCMEXUKQ).

${ }^{37}$ Source: OECD Productivity Database, multifactor productivity index 2008-2009, retrieved on December 19, 2017 (http://stats.oecd.org/).
} 


\subsection{Robustness}

Some robustness checks of the parametrization were carried out on both the implied deterministic steady state and the model dynamics. The choice of parameters controlling preferences and production technology are standard; we focus on the novel parametrization, beginning with their impact on the steady-state equilibrium. Specifically, we test the parameter calibration by ignoring the target, choosing alternative values, but recalibrating the other parameters to hit the other calibration targets. Increasing the share of firms that have an observable state, $\eta$, dilutes the asymmetric information problem. The financial constraints in the banking sector are independent of $\eta$, so the default threshold leading to credit tightening is unchanged. However, because the proportion of firms affected by adverse selection falls in $\eta$, the impact of credit crunches on aggregate outcomes weakens, and fluctuations in TFP are smaller. If we consider secular increases in $\eta,{ }^{38}$ holding other parameters constant, we find that, although having a smaller impact on the macroeconomy, credit crunches occur with higher frequency. Because new firms have an increased probability of being a corporate, and receiving surplus $\mathbb{E}_{t}\left[R_{t+1}^{s}-R_{t}\right]$, firm entry goes up. The larger number of firms and, in particular, the larger proportion of observable-project corporates reduces the interest spread and the average return on capital. As highlighted in Proposition 2, a lower capital return shifts the default threshold down, so it takes a smaller rise in default to generate credit contractions.

The fixed cost of entry, $F$, is chosen to target the rate of firm entry. Increasing $F$ will reduce firm entry and thus raise profits until the value of a new firm, $V_{t}=F$. Fewer firms will result in a higher return on capital and increased investment wedge. This would cause the default threshold, $d^{*}$, to shift down; however, with fewer firms seeking loans, the proportion of safe firms that receive funds, $x^{s}$, increases, raising $d^{*}$. To hit the calibration target of the share of risky loans, $\lambda$ is calibrated to a lower value so there are fewer safe firms in the economy. This moves $d^{*}$ down again, reinforcing the effect of a higher return to capital and causing an overall increase in financial instability under higher entry costs. The combined effect, however, is fairly modest.

As would be expected given their role in the optimal contract, the calibrations of $p$ and $\lambda$ do have a significant impact on both the stationary and dynamic equilibrium. If $\lambda$ is increased, the adverse selection problem weakens because, with fewer risky borrowers, the information rents are reduced. ${ }^{39}$ Furthermore, a lower $\lambda$ or $\bar{p}$ also imply great financial instability. ${ }^{40}$ Fewer safe firms

\footnotetext{
${ }^{38}$ The share of large businesses has increased from $46 \%$ of establishments in 1988 to $53 \%$ in 2015 (see footnote $22)$.

${ }^{39}$ For example, a $1 \%$ increase in TFP, $z_{t}$, causes a $4.3 \%$ rise in investment under the baseline calibration. This would be $4.4 \%$ with either the steady-state default rate, $d=1-p, 1$ percentage point higher, or the share of safe firms, $\lambda, 10 \%$ lower. See impulse responses in figures 11-15 in Appendix B.

${ }^{40}$ The implication is that stochastic volatility in $\lambda$ could be an additional source of macroeconomic volatility. An exogenous fall in $\lambda$ has a similar impact to a positive risk shock, so we only consider the latter. This seems a natural choice given the clear counter-cyclical time series of firm default.
} 
imply higher information rents, shifting in the default threshold so credit contractions become more likely (see equation (3.1)). Likewise, a higher steady-state default rate would be closer to the threshold, $d^{*}$, so a smaller risk shock would be needed to reach it.

\subsection{Instability and the Real Interest Rate}

As stated in proposition 2, the interest rate affects the likelihood of a credit contraction as the default threshold, $d^{*}$, above which the economy will be in the capital-misallocation regime, rises in the interest rate. Figure 7 plots the impulse response functions to a 1 standard deviation risk
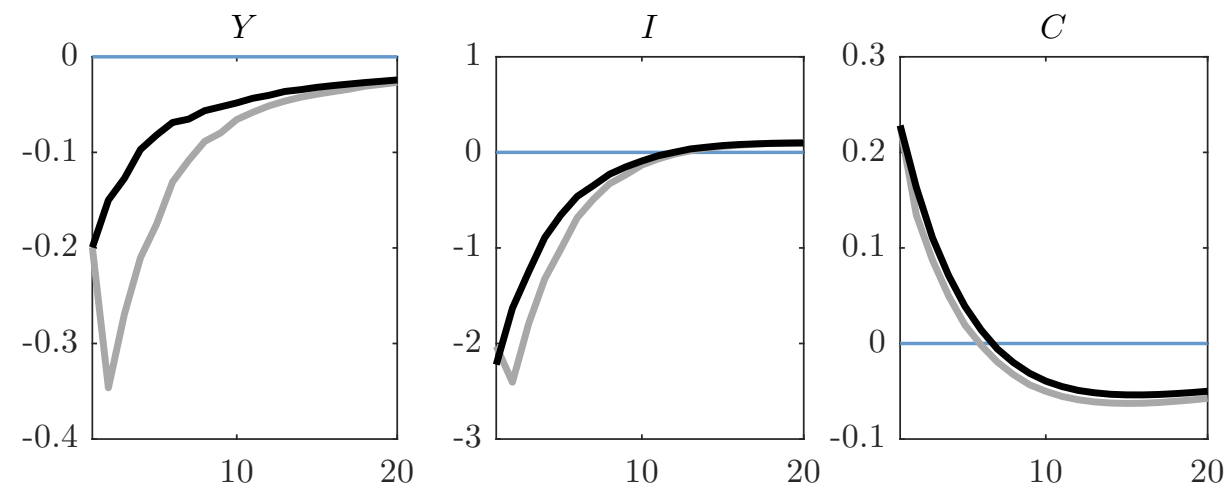

Figure 7: Impulse response functions to a 1 s.d. transitory risk shock comparing baseline calibration (black line) with a low $\bar{R}$ calibration (gray line). Time is quarterly, and plots show percentage deviation from ergodic mean for $Y, I$ and $C$, and percentage point deviation for $x^{s}, \Delta$ and $R$.

shock, as in figure 4 , but this time including a simulation with $\beta=0.993$, thus cutting $\bar{R}$ by a bit more than $1 \%$ annualized. The reduced interest rate shifts $d^{*}$ such that a 1 standard deviation shock is large enough to cause banks to restrict lending, leading to a sharp downturn.

The result of financial instability with lower interest rates finds support in the data. Figure 8 plots 10-year rolling averages of the real interest rate and output volatility. ${ }^{41}$ There is a negative trend on the whole dataset; however, it is interesting to sort the data into three subsets. The red squares represent the middle episode, 1977-1987, which, by virtue of the rolling window, captures observations from 1972 and includes the impact of the 1973 oil crisis and heightened volatility in the 1970s and early 1980s. The green circles include data between 1988 and 2011, covering the Great Moderation, and the black diamonds represent observations between 1966 and 1976. The negative relationship between the real interest rate and volatility supports our

\footnotetext{
${ }^{41}$ Centered on sixth year. Real interest rate from International Monetary Fund, International Financial Statistics and data files using World Bank data on the GDP deflator. Output deflated using GDP deflator (both U.S. Bureau of Economic Analysis) and divided by civilian noninstitutional population (U.S. Bureau of Labor Statistics), then logged and HP-filtered.
} 


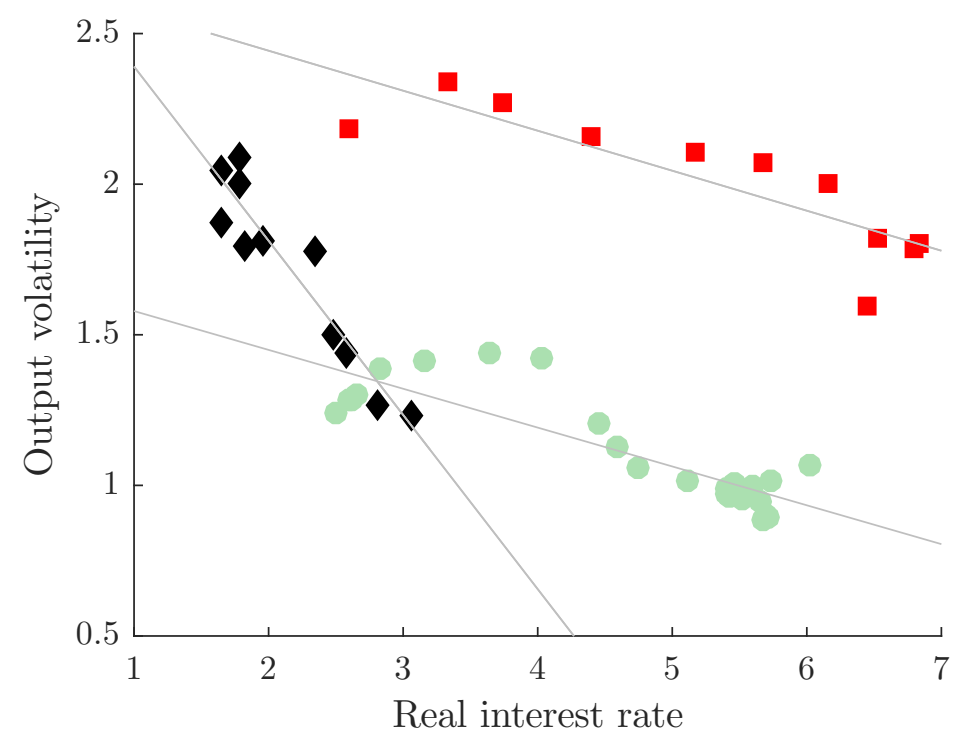

Figure 8: 10-year rolling average U.S. real interest rates against 10-year rolling average U.S. output volatility. 1966-1976 black diamonds; 1978-1987 red squares; and 1988-2011 green circles.

results. Shifts in these curves are likely due to structural factors not in the model, such as the evolving size and nature of financial markets, but could also be partly explained by the share of small establishments, which has been in steady decline. ${ }^{42}$ A higher share of large firms would reduce the adverse selection and indicate a dampening of volatility and could, in part, lie behind the reduced volatility during the Great Moderation, off-setting the declining real interest rate.

\section{Conclusion}

Banks vary the availability of business loans in response to economic conditions by both adjusting interest rates and by varying credit standards. These non-price standards play a potentially important but underexamined role in generating business cycles in advanced economies. In this paper, we have presented a model in which endogenous credit standards emerge from an information asymmetry between bank and borrower relating to a project's riskiness, the result of which are occasional credit crunches that are observationally equivalent to exogenous productivity shocks through the lens of a standard DSGE model. This contributes to a literature studying models with endogenous volatility in TFP. The existing macroeconomic literature on financial frictions has largely concentrated on mechanisms in which movements are due to misallocation of factors on the intensive margin, that is, capital not being allocated to the most productive

\footnotetext{
${ }^{42}$ For example, the share of small establishments has decreased from $54 \%$ in 1988 to $47 \%$ in 2015 (see footnote 22)
} 
firms. In this paper, the misallocation occurs on the extensive margin, where banks restrict the total volume of lending and store capital instead. The evidence has indicated that both margins affect cyclical movements in TFP (see, e.g., Franklin et al., 2018).

The mechanism is simple. Firms vary in their privately observed risk, even when expected pay-offs are the same. Lenders can separate borrowers by offering loans with different pairs of interest rates and loan approval ratings; risky borrowers will choose higher interest rates with higher approval probabilities, while safer borrowers will choose lower interest rates with lower approval probabilities. This positive correlation between loan interest rates and approval probabilities finds support in the data. When risky firms are very risky, the lenders will ration credit to safe firms in order to raise risky borrowing rates, causing drops in TFP. Due to the effect on productivity, through the lens of an RBC model, the risk shock appears as a combination of a negative technology shock and a tax on the return to capital. In the majority of existing macroeconomic models, however, the financial friction only emerges as the latter. This difference allows the model to capture the size of the fall in output observed during the financial crisis without requiring exogenous capital quality or productivity shocks.

The mechanism also introduces a financial accelerator that can help explain why spreads are more volatile than would be expected by changes in the default premia (the credit spread puzzle, see Gilchrist and Zakrajšsek (2012)). Furthermore, the default threshold increases in the interest rate, implying that financial instability, and therefore volatility, is heightened with low interest rates, as supported by the empirical evidence (see figure 8).

In the model, credit rationing is concentrated on safe SMEs, while risky and corporate firms do not face borrowing restrictions. During the 2008-2009 financial crisis, contractions in credit primarily affected the bank lending channel, so, as corporate firms have access to alternative sources of finance (see De Fiore and Uhlig, 2015), the adverse effects fell predominantly on SMEs (see also Fraser, 2012). Furthermore, while credit standards were tightened overall during the downturn, conditional on observables, loan rejection rates were found to increase for less-risky small businesses but not for riskier firms (Armstrong et al., 2013).

In summary, we have presented a novel contribution to our understanding of the channels by which financial disturbances might have real effects. Particularly relevant currently are the increased risks associated with lower interest rates. 


\section{References}

Adjemian, S., Bastanie, H., Karamé, F., Juillard, M., Maih, J., Mihoubi, F., Perendia, G., Pfeifer, J., Ratto, M. and Villemot, S. (2011), 'Dynare: Reference Manual Version 4', Dynare Working Paper Series (1), 160.

Albertazzi, U., Bottero, M., Gambacorta, L. and Ongena, S. (2017), Asymmetric Information and the Securitization of SME Loans, No. 601, BIS Working Papers, Bank for International Settlements.

Armstrong, A., Davis, P. E., Liadze, I. and Rienzo, C. (2013), Evaluating Changes in Bank Lending to UK SMEs over 2001-12 - Ongoing Tight Credit? Report, Department for Business, Innovation and Skills, London, UK.

Aruoba, S. B., Cuba-Borda, P. and Schorfheide, F. (2018), 'Macroeconomic Dynamics Near the ZLB: A Tale of Two Countries', Review of Economic Studies 85(1), 87-118.

Banerjee, A. V. and Moll, B. (2010), 'Why Does Misallocation Persist?' American Economic Journal: Macroeconomics 2(1), 189-206.

Barkley, B., Mills, C. K., Recto, M. C., Terry, E. and Wavering, E. (2016), 2015 Small Business Credit Survey: Report on Employer Firms, Technical report, Federal Reserve Banks of New York, Atlanta, Boston, Cleveland, Philadelphia, Richmond and St. Louis.

Battisto, J., de Zeeuw, M., Mills, C. K., Lieberman, S. and Wiersch, A. M. (2018), 2017 Small Business Credit Survey: Report on Employer Firms, Technical report, Federal Reserve Banks of Atlanta, Boston, Chicago, Cleveland, Dallas, Kansas City, Minneapolis, New York, Philadelphia, Richmond, St. Louis and San Francisco.

Beltran, D. O. and Thomas, C. P. (2010), Could Asymmetric Information Alone Have Caused the Collapse of Private-Label Securitization? No. 1010, Board of Governors of the Federal Reserve System, International Finance Discussion Papers.

Benhabib, J., Dong, F. and Wang, P. (2018), 'Adverse Selection and Self Fulfilling Business Cycles', Journal of Monetary Economics 94, 114-130.

Bernanke, B. S., Gertler, M. and Gilchrist, S. (1999), The Financial Accelerator in a Quantitative Business Cycle Framework, in J. B. Taylor and M. Woodford, eds, Handbook of Macroeconomics, Vol. 1, Elsevier B.V., chapter 21, pp. 1341-1393.

Bertsch, C. (2013), A Detrimental Feedback Loop: Deleveraging and Adverse Selection, No. 108, Sveriges Riksbank Research Paper Series.

Besanko, D. and Thakor, A. V. (1987), 'Competitive Equilibrium in the Credit under Asymmetric Information', Journal of Economic Theory 42(1), 167-182. 
Bester, H. (1985), 'Screening vs Rationing in Credit Markets with Imperfect Information', The American Economic Review 75(4), 850-855.

Bolton, P. and Dewatripont, M. (2005), Contract Theory, 1st edn, The MIT Press, Cambridge, MA.

Brunnermeier, M. and Sannikov, Y. (2014), 'A Macroeconomic Model with a Financial Sector', American Economic Review 104(2), 379-421.

Buera, F. J. and Shin, Y. (2013), 'Financial Frictions and the Persistence of History: A Quantitative Exploration', Journal of Political Economy 121(2), 221-272.

Caggese, A. and Cuñat, V. (2013), 'Financing Constraints, Firm Dynamics, Export Decisions, and Aggregate Productivity', Review of Economic Dynamics 16(1), 177-193.

Camargo, B. and Lester, B. (2014), 'Trading Dynamics in Decentralized Markets with Adverse Selection', Journal of Economic Theory 153(1), 534-568.

Chari, V. V., Kehoe, P. J. and McGrattan, E. R. (2007), 'Business Cycle Accounting', Econometrica 75(3), 781-836.

Chiu, J. and Koeppl, T. V. (2016), 'Trading Dynamics with Adverse Selection and Search: Market Freeze, Intervention and Recovery', Review of Economic Studies 83(3), 969-1000.

Christiano, L. J., Eichenbaum, M. S. and Trabandt, M. (2015), 'Understanding the Great Recession', American Economic Journal: Macroeconomics 7(1), 110-167.

Christiano, L., Motto, R. and Rostagno, M. (2010), Financial Factors in Economic Fluctuations, Working paper series, No. 1192, European Central Bank.

Christiano, L., Motto, R. and Rostagno, M. (2014), 'Risk Shocks', American Economic Review 104(1), 27-65.

Clementi, G. L. and Hopenhayn, H. A. (2006), 'A Theory of Financing Constraints and Firm Dynamics', Quarterly Journal of Economics 121(1), 229-265.

Crawford, G. S., Pavanini, N. and Schivardi, F. (2018), 'Asymmetric Information and Imperfect Competition in Lending Markets', American Economic Review 108(7), 1659-1701.

Cressy, R. and Toivanen, O. (2001), 'Is There Adverse Selection in the Credit Market?' Venture Capital 3(3), 215-238.

De Fiore, F. and Uhlig, H. (2015), 'Corporate Debt Structure and the Financial Crisis', Journal of Money, Credit and Banking 47(8), 1571-1598.

De Meza, D. and Webb, D. C. (1987), 'Too Much Investment: A Problem of Asymmetric Information', The Quarterly Journal of Economics 102(2), 281-292. 
Fernald, J. (2014), A Quarterly, Utilization-Adjusted Series on Total Factor Productivity, Working paper 2012-19, Federal Reserve Bank of San Francisco.

Fernández-Villaverde, J., Gordon, G., Guerrón-Quintana, P. and Rubio-Ramírez, J. F. (2015), 'Nonlinear Adventures at the Zero Lower Bound', Journal of Economic Dynamics and Control $\mathbf{5 7}(\mathrm{C}), 182-204$.

Figueroa, N. and Leukhina, O. (2018), 'Cash Flows and Credit Cycles', Journal of Banking 6 Finance 87, 318-332.

Franklin, J., Rostom, M. and Thwaites, G. (2018), 'The Banks that Said No: Banking Relationships, Credit Supply and Productivity in the United Kingdom', Journal of Financial Services Research (Forthcoming).

Fraser, S. (2012), The Impact of the Financial Crisis on Bank Lending to SMEs, Technical report, U.K. Government Department for Business Innovation and Skills. Report Prepared for BIS/ Breedon Review.

Gertler, M. and Kiyotaki, N. (2010), 'Financial Intermediation and Credit Policy in Business Cycle Analysis', Handbook of Monetary Economics 3(11), 547-599.

Gilchrist, S., Sim, J. W. and Zakrajšek, E. (2013), 'Misallocation and Financial Market Frictions: Some Direct Evidence from the Dispersion in Borrowing Costs', Review of Economic Dynamics 16(1), 159-176.

Gilchrist, S. and Zakrajšek, E. (2012), 'Credit Spreads and Business Cycle Fluctuations', American Economic Review 102(4), 1692-1720.

Guerrieri, V., Shimer, R. and Wright, R. (2010), 'Adverse Selection in Competitive Search Equilibrium', Econometrica 78(6), 1823-1862.

He, Z. and Krishnamurthy, A. (2013), 'Intermediary Asset Pricing', American Economic Review 103(2), 732-770.

Hellwig, M. F. (1987), 'Some Recent Developments in the Theory of Competition in Markets with Adverse Selection', European Economic Review 31(1-2), 319-325.

Holden, T. (2016), Computation of Solutions to Dynamic Models with Occasionally Binding Constraints, Econstor Preprints 144569, ZBW - Leibniz Information Centre for Economics.

Holden, T. D., Levine, P. and Swarbrick, J. M. (2019), 'Credit Crunches from Occasionally Binding Bank Borrowing Constraints', Journal of Money, Credit and Banking (Forthcoming).

House, C. L. (2006), 'Adverse Selection and the Financial Accelerator', Journal of Monetary Economics 53(6), 1117-1134. 
Jeong, H. and Townsend, R. M. (2007), 'Sources of TFP Growth: Occupational Choice and Financial Deepening', Economic Theory 32(1), 179-221.

King, R. G., Plosser, C. I. and Rebelo, S. T. (1988), 'Production, Growth and Business Cycles', Journal of Monetary Economics 21(2-3), 309-341.

Kiyotaki, N. and Moore, J. (1997), 'Credit Cycles', Journal of Political Economy 105(2), 211248.

Kurlat, P. (2013), 'Lemons Markets and the Transmission of Aggregate Shocks', American Economic Review 103(4), 1463-1489.

Lester, B., Postlewaite, A. and Wright, R. (2011), 'Information and Liquidity', Journal of Money, Credit and Banking 43(SUPPL. 2), 355-377.

Lian, C., Ma, Y. and Wang, C. (2018), 'Low Interest Rates and Risk Taking: Evidence from Individual Investment Decisions', Review of Financial Studies (Forthcoming).

Lown, C. S. and Morgan, D. P. (2006), 'The Credit Cycle and the Business Cycle: New Findings Using the Loan Officer Opinion Survey', Journal of Money, Credit and Banking 38(6), 15751597.

Mankiw, N. G. (1986), 'The Allocation of Credit and Financial Collapse', Quarterly Journal of Economics 101(3), 455-470.

Martin, A. (2009), 'A Model of Collateral, Investment, and Adverse Selection', Journal of Economic Theory 144(4), 1572-1588.

Moll, B. (2014), 'Productivity Losses from Financial Frictions: Can Self-Financing Undo Capital Misallocation?' American Economic Review 104(10), 3186-3221.

Morris, S. and Shin, H. S. (2012), 'Contagious Adverse Selection', American Economic Journal: Macroeconomics 4(1), 1-21.

Oberfield, E. (2013), 'Productivity and Misallocation during a Crisis: Evidence from the Chilean Crisis of 1982', Review of Economic Dynamics 16(1), 100-119.

Pratap, S. and Urrutia, C. (2012), 'Financial Frictions and Total Factor Productivity: Accounting for the Real Effects of Financial Crises', Review of Economic Dynamics 15(3), 336-358.

Reichlin, P. and Siconolfi, P. (1998), 'Adverse Selection of Investment Projects and the Business Cycle', Temi di discussione, Banca d'Italia 326(November), 1-28.

Robb, A. and Farhat, J. (2013), An Overview of the Kauffman Firm Survey: Results from 2011 Business Activities, Technical report, Ewing Marion Kauffman Foundation. 
Rocheteau, G. (2011), 'Payments and Liquidity under Adverse Selection', Journal of Monetary Economics 58(3), 191-205.

Rothschild, M. and Stiglitz, J. (1976), 'Equilibrium in Competitive Insurance Markets: An Essay on the Economics of Imperfect Information', The Quarterly Journal of Economics 90(4), 629649 .

Scheuer, F. (2013), 'Adverse Selection in Credit Markets and Regressive Profit Taxation', Journal of Economic Theory 148(4), 1333-1360.

Shin, H. S. (2009), 'Reflections on Northern Rock: The Bank Run that Heralded the Global Financial Crisis', Journal of Economic Perspectives 23(1), 101-119.

Stiglitz, J. E. and Weiss, A. (1981), 'Credit Rationing in Markets with Imperfect Information', American Economic Review 71(3), 393-410.

Stiglitz, J. E. and Weiss, A. (1992), 'Asymmetric Information in Credit Markets and Its Implications for Macro-economics', Oxford Economic Papers 44(4), 694-724.

Tang, T. T. (2009), 'Information Asymmetry and Firms' Credit Market Access: Evidence from Moody's Credit Rating Format Refinement', Journal of Financial Economics 93(2), 325-351.

Tomura, H. (2012), 'Asset Illiquidity and Market Shutdowns in Competitive Equilibrium', Review of Economic Dynamics 15, 283-294.

Williamson, S. D. (1986), 'Costly Monitoring, Financial Intermediation, and Equilibrium Credit Rationing', Journal of Monetary Economics 18(2), 159-179.

Williamson, S. and Wright, R. (1994), 'Barter and Monetary Exchange under Private Information', The American Economic Review 84(1), 104-123.

Wilson, C. (1977), 'A Model of Insurance Markets with Incomplete Information', Journal of Economic Theory 16(2), 167-207. 


\section{Appendix A Propagation of Technology Shocks}

Following a positive transitory shock to aggregate productivity, $z_{t}$, in both our model and the RBC model there is an increase in all variables via the standard channel. Plots of impulse
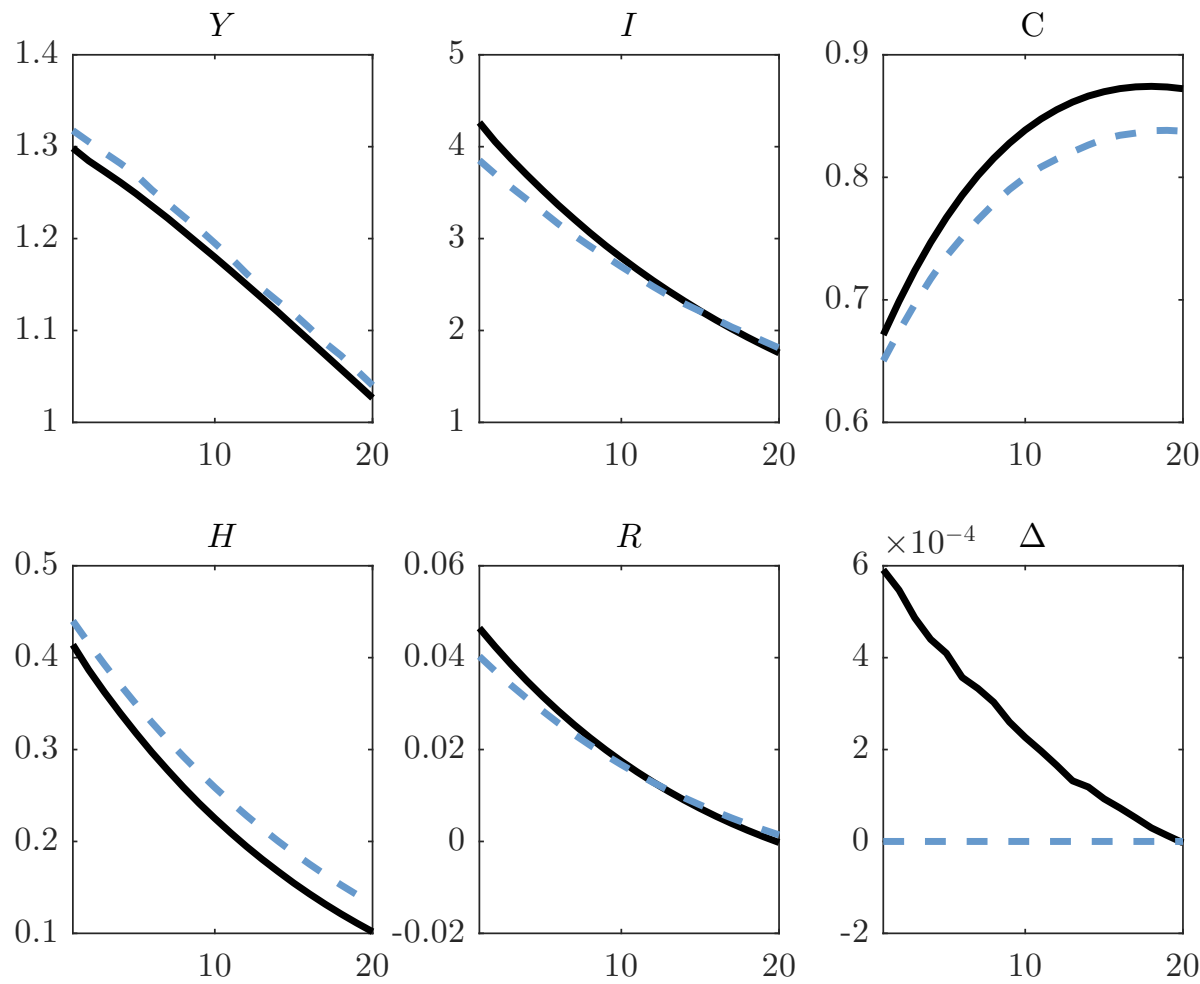

Figure 9: Average impulse response functions to a positive transitory shock to technology $z_{t}$ of $1 \%$ for our model (black line) and the RBC (blue dashed). Time is quarterly, and plots show percentage point deviation from ergodic mean for $R$ and $\Delta$, and percent deviation for other variables.

response functions to a positive shock to $z_{t}$ of $1 \%$ are shown in figure 9 . In the adverse selection economy, both risky and safe project returns increase, and there is a small rise in the interest spread, $\Delta_{t}$. On first look, investment and consumption appear more volatile in the model with adverse selection, but output less so. This is a compositional effect; while the steady-state share of investment in our model is about $17.4 \%$ of GDP, in line with the U.S. data, the share is $20.8 \%$ of GDP in the RBC model. This follows from the parameterization of $\delta, \beta$ and $\alpha$. The additional volatility is caused by the presence of a positive steady-state spread, reducing the average level of investment and consumption. If the RBC model were solved with a constant spread equal to the average spread in our model, we would actually observe a small deceleration effect as the information rents increase, mildly reducing the marginal efficiency of investment. However, the effect is quantitatively negligible. 


\section{Appendix B Figures}
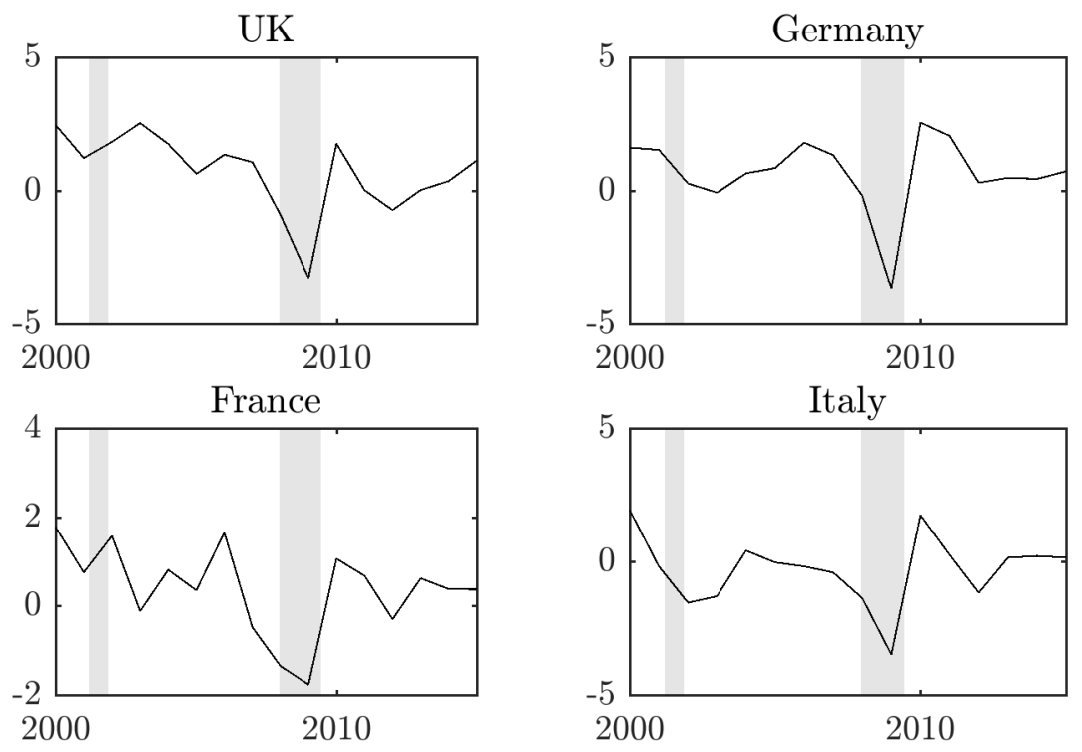

Figure 10: Percent growth rate in multifactor productivity with National Bureau for Economic Research (NBER) recession bands. Source: OECD.
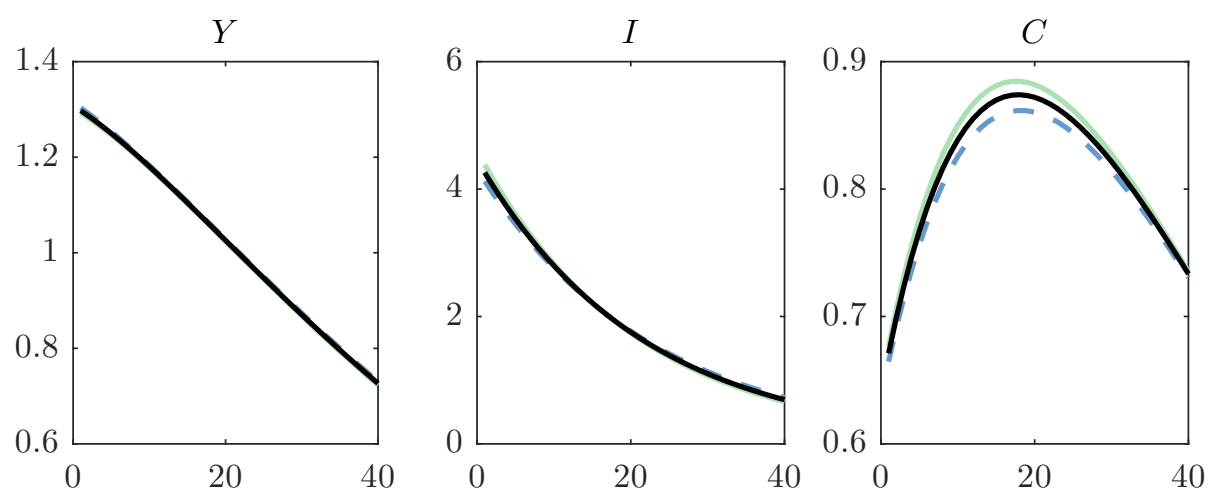

Figure 11: Impulse response functions to a positive transitory shock to technology $z_{t}$ of $1 \%$ comparing baseline calibration (black line) with high $\lambda(+10 \%)$ (blue dashed) and low $\lambda(-10 \%)$ (green line). Time is quarterly, and plots show percent point deviation from ergodic mean. 


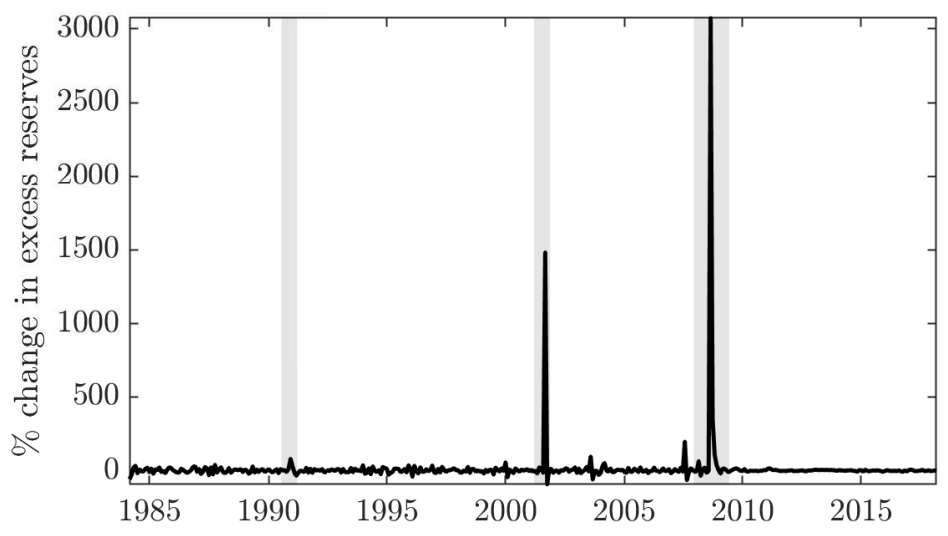

Figure 12: Percentage change in excess reserves of U.S. depository institutions. Source: Federal Reserve Bank of St. Louis, H.3 Aggregate Reserves of Depository Institutions and the Monetary Base.
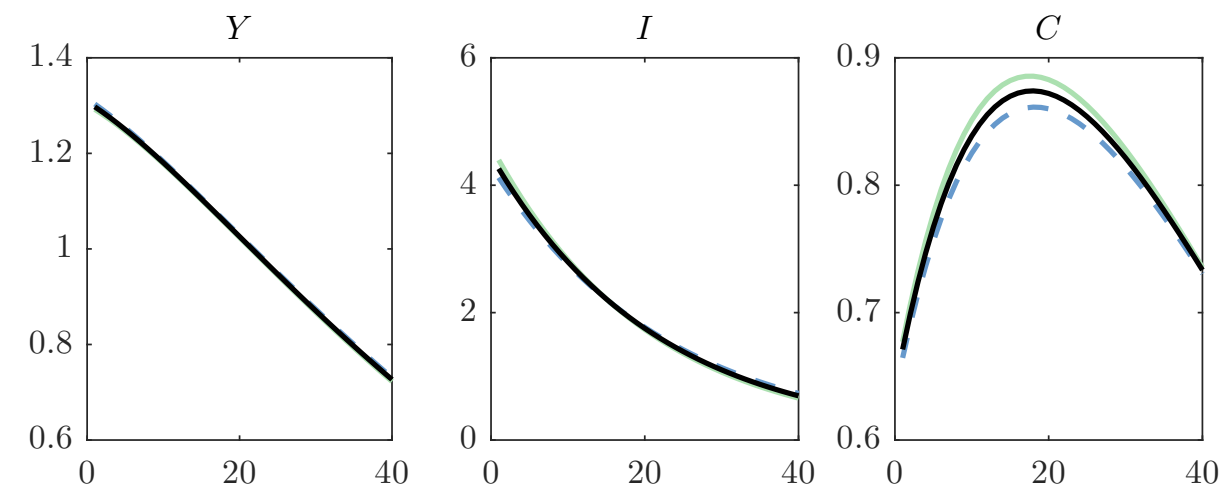

Figure 13: Impulse response functions to a positive transitory shock to technology $z_{t}$ of $1 \%$ comparing baseline calibration (black line) with high steady state $p(+1 \% \mathrm{pt})$ (blue dashed) and low $p(-1 \% \mathrm{pt})$ (green line). Time is quarterly, and plots show percent point deviation from ergodic mean. 

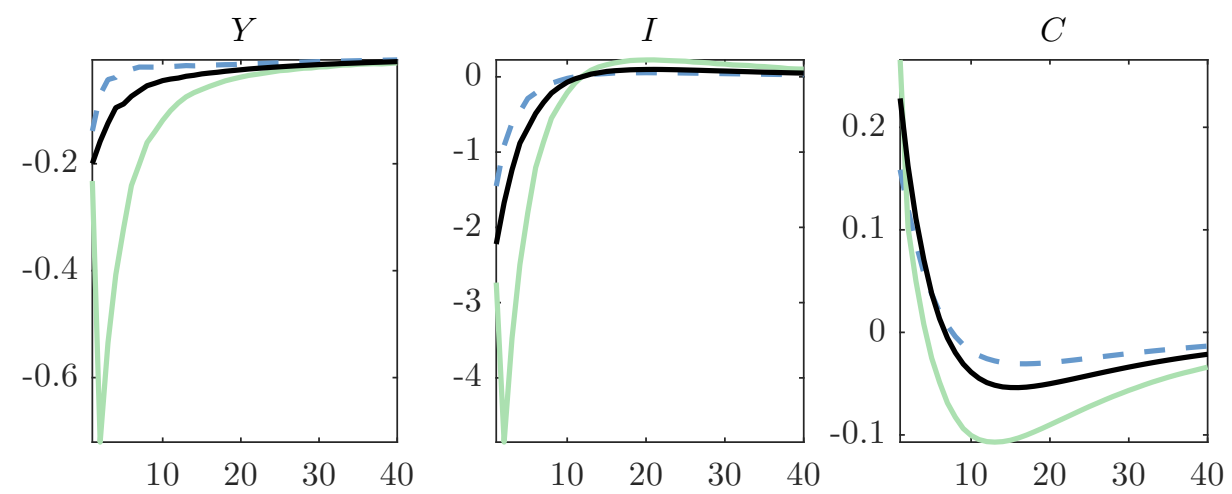

Figure 14: Impulse response functions to a negative transitory 1 s.d. shock to $p_{t}$ comparing baseline calibration (black line) with high $\lambda(+10 \%)$ (blue dashed) and low $\lambda(-10 \%)$ (green line). Time is quarterly, and plots show percent point deviation from ergodic mean.
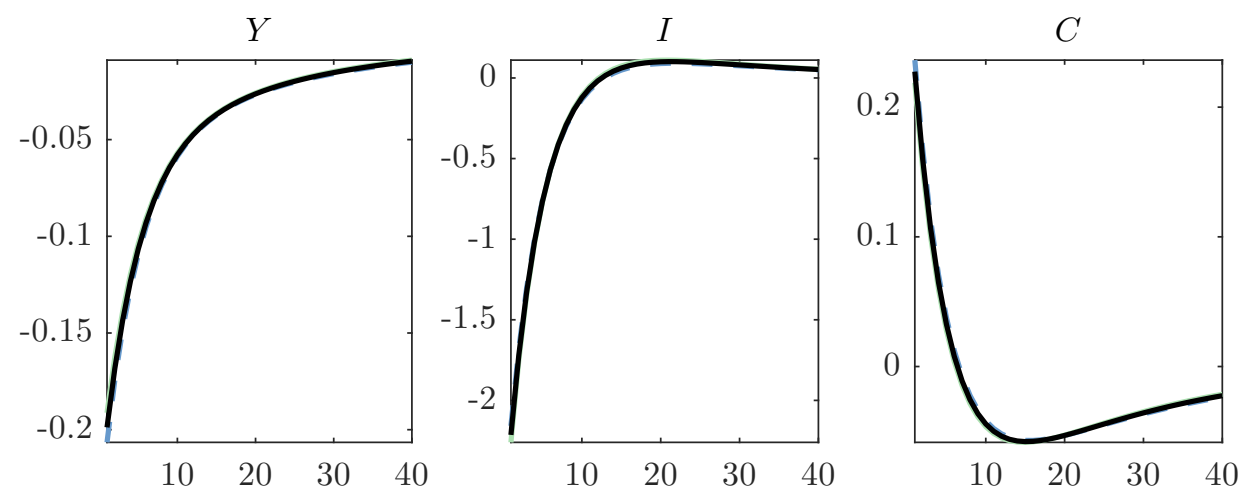

Figure 15: Impulse response functions to a negative transitory 1 s.d. shock to $p_{t}$ comparing baseline calibration (black line) with high steady-state $p(+1 \% \mathrm{pt}$ ) (blue dashed) and low $p(-1 \% \mathrm{pt})$ (green line). Time is quarterly, and plots show percent point deviation from ergodic mean. 


\section{Appendix C Contract Conditions}

The IR and IC constraints are

$$
\begin{gathered}
\mathbb{E}_{t}\left[\Lambda_{t, t+1} p_{t+1}^{i}\left(R_{t+1}^{i}-\tau_{t}^{i}\right)\right] \geq 0, \quad i=r, s \\
\mathbb{E}_{t}\left[\Lambda_{t, t+1} p_{t+1}^{i} x_{t}^{i}\left(R_{t+1}^{i}-\tau_{t}^{i}\right)\right] \geq \mathbb{E}_{t}\left[\Lambda_{t, t+1} p_{t+1}^{i} x_{t}^{j}\left(R_{t+1}^{i}-\tau_{t}^{i}\right)\right], \quad i, j=r, s ; i \neq j .
\end{gathered}
$$

There must be one binding IR and one binding IC constraint. Given that $R_{t+1}^{r}>R_{t+1}^{s} \geq \tau_{t}^{s}$, we can write

$$
\begin{aligned}
\mathbb{E}_{t}\left[\Lambda_{t, t+1} p_{t+1}^{r} x_{t}^{r}\left(R_{t+1}^{r}-\tau_{t}^{r}\right)\right] & \geq \mathbb{E}_{t}\left[\Lambda_{t, t+1} p_{t+1}^{r} x_{t}^{s}\left(R_{t+1}^{r}-\tau_{t}^{s}\right)\right] \\
& >\mathbb{E}_{t}\left[\Lambda_{t, t+1} p_{t+1}^{r} x_{t}^{s}\left(R_{t+1}^{s}-\tau_{t}^{s}\right)\right] \geq 0
\end{aligned}
$$

Then $\mathbb{E}_{t}\left[\Lambda_{t, t+1} p_{t+1}^{s}\left(R_{t+1}^{s}-\tau_{t}^{s}\right)\right] \geq 0$ must be the binding IR constraint, which implies that (C.3) is the binding IC constraint. Using the binding safe IR constraint, the safe IC constraint can be written

$$
0 \geq \mathbb{E}_{t}\left[\Lambda_{t, t+1} p_{t+1}^{s} x_{t}^{r}\left(\tau_{t}^{s}-\tau_{t}^{r}\right)\right]
$$

implying $\tau_{t}^{r} \geq \tau_{t}^{s}$. Substituting this into the binding risky IC constraint yields

$$
\mathbb{E}_{t}\left[\Lambda_{t, t+1} p_{t+1}^{r} x_{t}^{r}\left(R_{t+1}^{r}-\tau_{t}^{r}\right)\right] \geq \mathbb{E}_{t}\left[\Lambda_{t, t+1} p_{t+1}^{r} x_{t}^{s}\left(R_{t+1}^{r}-\tau_{t}^{r}\right)\right],
$$

from which $x_{t}^{r} \geq x_{t}^{s}$ follows.

\section{Appendix D Proofs}

Proof 1 (Proof of proposition 1) Using equations (2.26) and (2.27) with $p_{t} R_{t}^{r}=R_{t}^{s}$, we find

$$
\mathbb{E}_{t}\left[\Lambda_{t, t+1} R_{t+1}^{s}\right]=\frac{\phi_{t}+\mathbb{E}_{t}\left[\Lambda_{t, t+1}\right]\left(\lambda x_{t}^{s}+(1-\lambda) x_{t}^{r}-\phi_{t}\right) r^{*}}{\lambda x_{t}^{s}+(1-\lambda)\left(x_{t}^{r}-x_{t}^{s}\left(1-\mathbb{E}_{t}\left[p_{t+1}\right]\right)\right)},
$$

where $\phi_{t} \equiv \frac{S_{t}}{(1-\eta) f_{t} k} \geq \lambda x_{t}^{s}+(1-\lambda) x_{t}^{r}$. It follows that $\mathbb{E}_{t}\left[\Lambda_{t, t+1} R_{t+1}^{s}\right]>1$ if

$$
\mathbb{E}_{t}\left[1-\Lambda_{t, t+1} r^{*}\right]\left(\phi_{t}-\lambda x_{t}^{s}-(1-\lambda) x_{t}^{r}\right)>-(1-\lambda)\left(x_{t}^{s} \mathbb{E}_{t}\left[\Lambda_{t, t+1}\left(1-p_{t+1}\right) R_{t}\right]\right),
$$

which must hold when $\mathbb{E}_{t}\left[\Lambda_{t, t+1} r^{*}\right] \leq 1$, which will when $r^{*} \leq R_{t}$. It follows from equation (2.6) that $\varrho+\varphi_{t}^{r}>0$. Substituting equation (2.6) into (2.7) then yields

$$
\mathbb{E}_{t}\left[\Lambda_{t, t+1}\left(1-p_{t+1}\right) R_{t+1}^{s}\right]=\varphi_{t}^{s}-\psi_{t} \frac{1}{1-\lambda}+\varphi_{t}^{r} \frac{\lambda}{1-\lambda}
$$

$p_{t}<1 \forall t$, and therefore $\varphi_{t}^{s}+\varphi_{t}^{r}>0$. It is straightforward to see from conditions (2.12)-(2.15) that if $\varphi_{t}^{s}>0$, then $\varrho=0$. Therefore, $\varphi_{t}^{r}>0$ and $x_{t}^{r}=1$. 